\title{
Where Is Lowland Maya Archaeology Headed?
}

\author{
Joyce Marcus ${ }^{1}$
}

This article isolates three important trends in Lowland Maya archaeology during the last decade: (1) increased use of the conjunctive approach, with renewed appreciation of context and provenience; (2) waning use of the label "unique" to describe the Maya; and (3) an effort to use the Lowland Maya as a case study in social evolution.

KEY WORDS: Maya archaeology; conjunctive approach; direct historic approach.

\section{INTRODUCTION}

I have been asked to review the last decade of Lowland Maya archaeology and discuss any major trends that can be discerned. The task presents numerous problems, not the least of which is the fact that one has little time to deliberate on data so newly produced. I also do not want to run the risk of extolling current research at the expense of that done by our predecessors. Finally, the volume of literature on Maya archaeology has been increasing so rapidly in recent years that one cannot hope to do more than cite a fraction of it. I have tried to compensate for this by including a 400-entry bibliography at the end of the review.

At least three major trends can be seen in the last decade of Lowland Maya archaeology, and I organize my presentation around them. The first trend is a substantial increase in the integration of multiple lines of evidence-in effect, what Walter W. Taylor (1948) called "the conjunctive approach" (Carmack and Weeks, 1981; Fash and Sharer, 1991, Marcus, 1983; Sabloff, 1990). This effort rarely has reached the point where it could be called "processual archaeology," because the latter requires that research

'Museum of Anthropology, Room 4009, 1109 Geddes Avenue, University of Michigan, Ann Arbor, Michigan 48109-1079. 
be designed from the outset to answer general questions of culture process. Nevertheless, it is increasingly commonplace to see the staffs of Lowland Maya projects integrating the work of surveyors, ethnohistorians, ceramicists, epigraphers, palynologists, human osteologists, faunal analysts, ethnobotanists, malacologists, chipped stone experts, and the like.

This trend is very encouraging, and my only caveat would be that the project director should guard against the temptation to mention only those cases where the varied lines of evidence agree. As more and more data are amassed, it is inevitable that we shall find cases where two or more lines of evidence show lack of fit: The archaeology may contradict the epigraphy, the ceramic style zones may not coincide with the territories claimed by rulers, the faunal remains may not fit with the palynology or plant macrofossils, and so on. Such lack of fit may be very important, since it forces us to search for new reconstructions and explanations that resolve conflicts in the data (Haviland, 1985, p. 41; 1991, p. 10; Marcus, 1992a, pp. xix, 443-445; Sharer, 1993a, p. 99).

Closely related to this increase in conjunctive approaches is a mounting concern with context and provenience, both of which are vital to developing convincing arguments from evidence. For example, Mayanists increasingly realize that lavish coffee table publications of looted artifacts not only reflect a lack of respect for archaeological context, but also encourage further looting of Latin America's patrimony (Coggins, 1972). As Dorie Reents-Budet (1994) correctly notes, "The context in which an object is found gives you 95 per cent of the cultural historical information. Only about 5 per cent comes from the object itself." Maya archaeology will be better off when the last remaining members of our profession who wink at looting have tripped over their bulging wallets and gone to an appropriate level of the Maya underworld.

The second trend I see is that the Maya are less frequently described as "unique." A belief in Maya "uniqueness" (which antedated the postprocessualists' belief in cultural uniqueness by decades) has been an albatross around our necks for a long time, preventing genuine comparisons with other parts of Mesoamerica. Now increased recognition of similarities between the Maya and their Mesoamerican contemporaries is overcoming our former parochialism.

The third trend (probably related to the second) is an increasing realization that the Maya have a role to play in the development of evolutionary theory. Stripped of their uniqueness, the Maya can serve-like the Zapotec, Teotihuacanos, or Chimu-as a case study in social evolution. While this trend is positive, most Mayanists are so unused to it that they occasionally have performed like theoretical Keystone Kops. Their biggest problem revolves around the selection of other world cultures that are ap- 
propriate analogies to the Maya state. We have seen the Maya compared to Aegean chiefdoms or segmentary societies like the unstratified Alur, and we have seen institutions typical of Siberian hunters and gatherers (such as shamanism) projected onto the Classic Maya state. Apparently, it is going to take Mayanists a while to "get the hang of this comparative thing."

\section{TREND I: RECENT FIELD RESEARCH, WITH ITS INCREASINGLY CONJUNCTIVE APPROACH}

One of the encouraging signs of the last decade is that it witnessed significant progress on all epochs of Maya prehistory: Paleoindian, Archaic, Preclassic, Classic, and Postclassic. We look at these periods in order.

\section{Paleoindian and Archaic Periods (10,000-2000 B.C.?)}

During the last 100 years of Lowland Maya archaeology, Paleoindian and Archaic sites had been largely ignored. In 1980, Richard S. MacNeish began the Belize Archaic Archaeological Reconnaissance to focus on these neglected periods. By cross-dating projectile point types with other regions of Mesoamerica, MacNeish tentatively divided the period 9000-2000 B.C. into six Archaic phases (MacNeish et al., 1980; MacNeish, 1981,1982; MacNeish and Nelken-Terner, 1983; Zeitlin, 1984). Most of the 60-80 sites MacNeish located were shallow, not permitting the kind of stratigraphic work he had done earlier in Tehuacán and Tamaulipas (see Fig. 1). The artifacts suggested to him that Archaic peoples relied on mixed strategies of plant collecting and hunting and that they occupied camps in different environmental zones during different seasons.

T. Hester and H. Shafer's Colha Regional Survey was initiated in 1979. Its principal goal was to locate chipped stone workshops for all periods in northern Belize's "chert-bearing zone" as defined by A. Wright et al. (1959). As a result of the Colha survey, several Paleoindian and Archaic discoveries were made (see Fig. 2). They include the oldest artifact known from Belize, a Paleoindian Clovis point from Ladyville (Hester $e t$ al., 1981). This point is regarded as similar to those found in Panama by Bird and Cooke (1978, Fig. 5A). The only other Clovis points known from the Maya region hail from the Maya Mountains of Belize and highland Guatemala (see Fig. 3); they are thought to date to ca. 10,000 B.C. (Brown, 1980; Dunham, 1994; Gruhn and Bryan, 1977).

Archaic points have been found at Lowe Ranch, Ladyville, and elsewhere in northern 'Belize. MacNeish's project and that of Hester and Shafer 


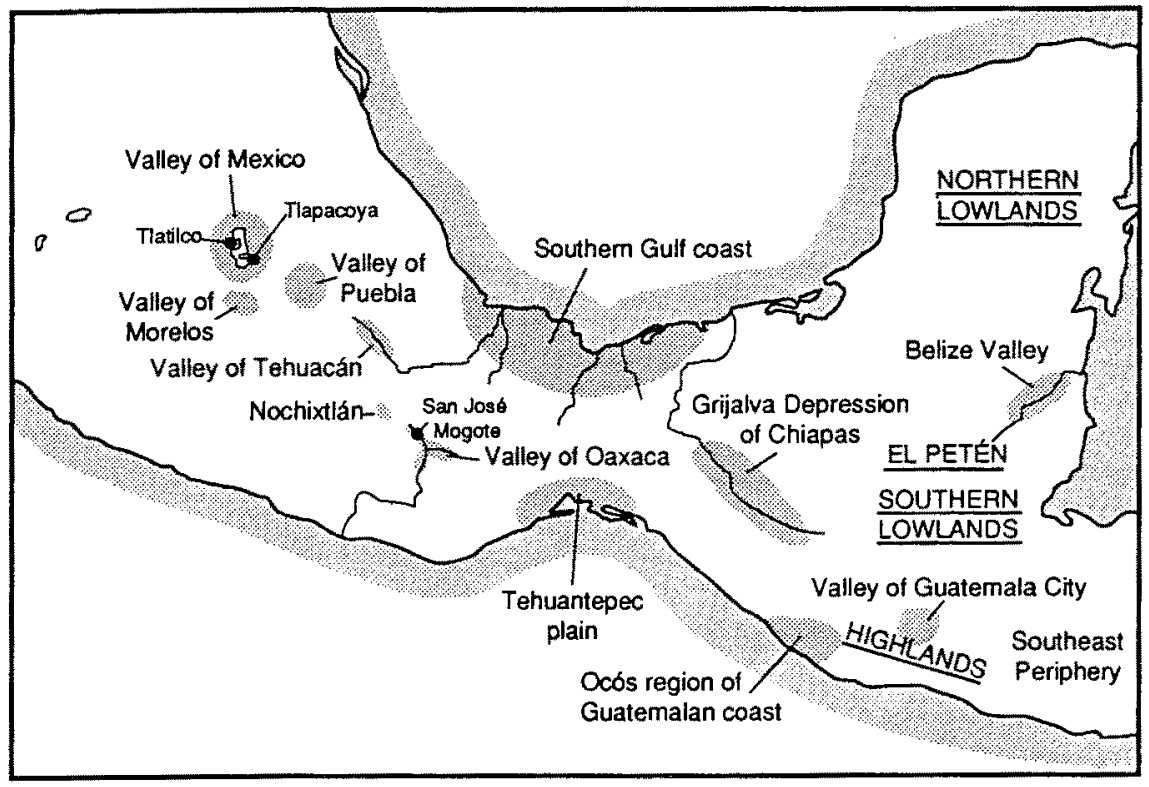

Fig. 1. Mesoamerica, showing some regions discussed in this article.

undertook excavations at Ladyville at different times; together their work yielded 13 projectile points from the surface and 3 found in situ (Kelly, 1993). Two of the Late Archaic points seem to be associated with a hearth dating to ca. 2000-1900 B.C. Kelly calls these artifacts "Lowe points." Two other point types, called "Sawhill" and "Allspice" by Kelly, may be more recent than the Lowe points.

If we follow Kelly's seriation of projectile points (as opposed to MacNeish's), we are left with a gap of 6000-8000 years between the Paleoindian period and the Late Archaic. If this gap is real, northern Belize would have been uninhabited during the Early Archaic for unexplained reasons. The gap, however, may simply be a consequence of too few stratified Archaic sites having been excavated in Belize.

Kelly (1993, p. 225) suggests that the Archaic chipped-stone technology of Belize is so different from that of later periods that the makers of the Archaic points must be considered "non-Maya" people who were later replaced by "Maya." This hypothesis of ethnic replacement, however, assumes a closer link between Maya speakers and chipped-stone technology than most analysts are willing to accept. Other regions of Mesoamerica show typological disconformities of this kind (for example, projectile points 


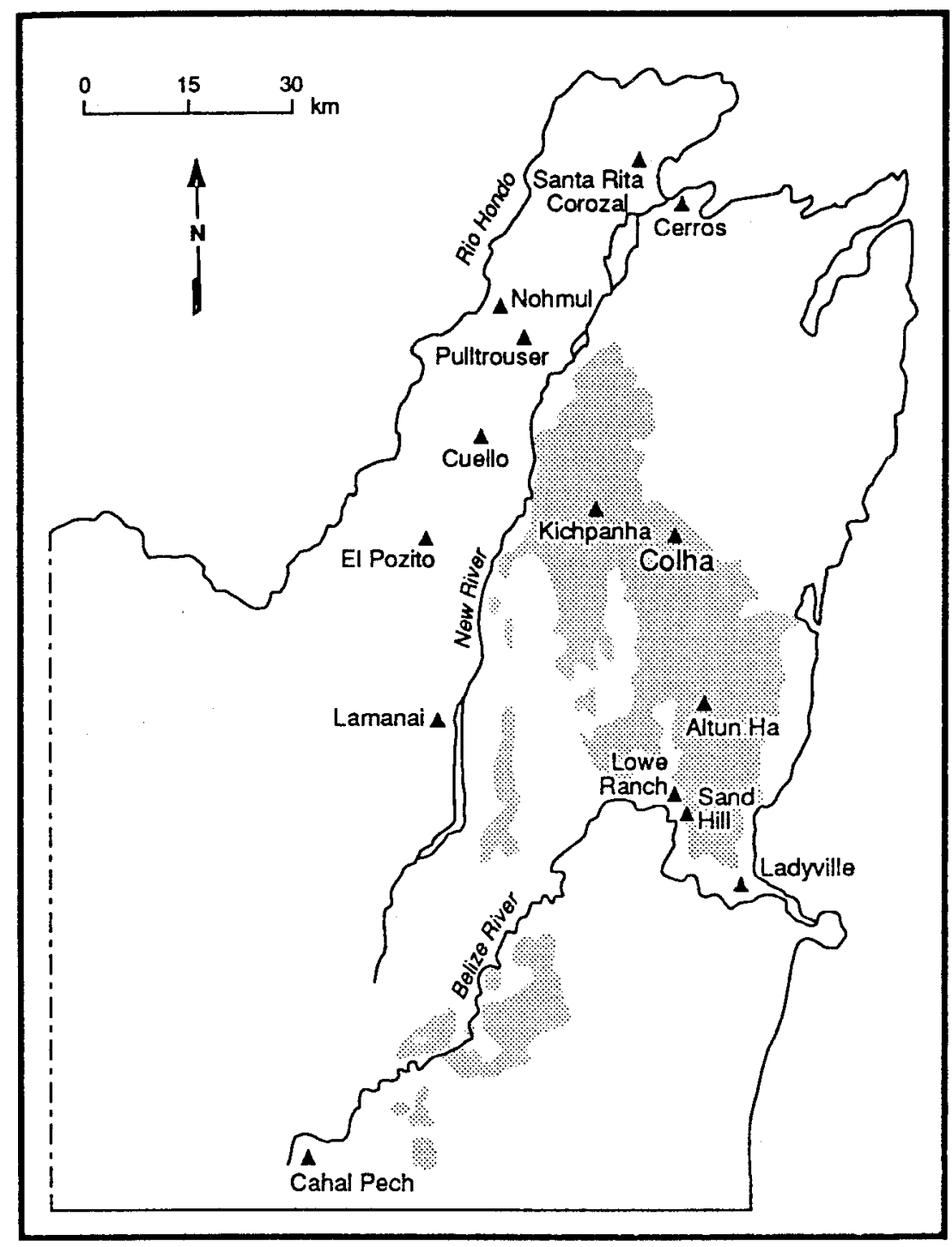

Fig. 2. Northern Belize, showing some of the earliest sites located near or on the chertbearing zone (shaded area).

virtually disappear in the Valley of Oaxaca and Grijalva Depression between the Late Archaic and the Early Formative). The changes could simply be technological, reflecting the shift from hunting and gathering to tree 
felling for agriculture. (In Oaxaca and the Grijalva, we suspect a shift from hunting deer with chert-tipped atlatl darts to hunting in larger groups with nets and fire-hardened spears like the Chiapanec.)

New work at Colha suggests significant continuity from Archaic to Middle Preclassic times. In the Middle Preclassic, Hester and Shafer see new tool types emerging in response to changing agricultural strategies. There is a shift away from the Archaic constricted unifaces and certain macroblade tools to Middle Preclassic bifacial celts and sharp T-shaped adzes/axes (forerunners of the tranchet bit tool). However, continuing use of macroblade tools bridges the gap between these assemblages (Shafer, personal communication, 1994). Both the Archaic tool assemblage and the pollen evidence (J. Jones, 1991) suggest a period of forest clearance, while the Middle Preclassic assemblage suggests other agricultural pursuits. In other words, once much of the Archaic rainforest surrounding Colha had been cleared, residents may have developed a different set of tools for farming the more open Middle Preclassic landscape.

Like Colha, Pulltrouser Swamp has yielded new data that suggest continuity from Late Archaic hunting and woodworking implements (a stemmed point and a constricted uniface) to Preclassic farming tools (adzes and celts) (Hester et al., 1993; Pohl et al., 1994). Employing a truly conjunctive approach to the Maya Archaic has been difficult, because chipped stone often constitutes the only solid line of evidence. We still lack systematic survey data from large sectors of the Lowlands, combined with extensive floral and environmental data (soils, pollen, and phytoliths), but $J$. Jones (1991) and Pohl et al. (1994) are collecting these sorts of data for the Archaic.

\section{The Archaic-Preclassic Transition}

A decade ago I pointed to a lack of data on the transition from the Archaic to the Preclassic in the Lowland Maya region, as well as a puzzling absence of Early Preclassic sites (Marcus, 1983, 1984).

Two current projects are providing data on the transition from Archaic to Preclassic times. Excavations at two northern Belize swampsColha's Cobweb Swamp (J. Jones, 1991; Hester, 1993; Hester et al., 1993; Shafer and Hester, personal communication, 1994) and Pulltrouser Swamp (Pohl et al., 1994)-appear to contain Archaic through Middle Preclassic materials in good stratigraphic context. At Pulttrouser Swamp, Pohl et al. have found a Late Archaic campsite (dated to 2300-1300 B.C.) that contains retouched chert flakes, blades, and scrapers, as well as one complete "Lowe point." (The point was associated with a piece of wood radiocar- 
bon-dated to 2300 B.C). Pohl et al. suggest that during the rainy season, inhabitants occupied this campsite to collect aquatic resources. Faunal remains include fish and turtle, with the turtle carapaces (Staurotypus) showing evidence of cutting and burning. During the dry season, when water levels were lower, the wetlands might have been cultivated. Pollen records from Pulltrouser Swamp and Cobweb Swamp reveal a major increase in fragments of particulate carbon and carbonized vegetation at ca. 2500 B.C., leading Jones and Pohl et al. to infer that extensive burning for forest clearance was taking place here, as it did at Colha (J. Jones, 1991). Maize pollen has been recovered, as well as pollen from "disturbance vegetation"grasses (Poaceae), composites (Asteraceae), Chenopodium, and Amaranthus (J. Jones, personal communication, 1994). Phytoliths of squash and bottle gourd were also found (D. Piperno, personal communication, 1994). J. Jones and Pohl et al. believe that they have evidence for extensive expansion of maize agriculture during this time.

\section{Early Preclassic (ca. 1200-900 B.C.)}

So far, it is only at Copán that we have clear evidence for an Early Preclassic period (Fash, 1982; 1991, pp. 67-69). In Group 9N-8 of that site, Fash excavated several burials with vessels bearing carved and incised motifs similar to those found at Tlatilco, Tlapacoya, and San José Mogote in the Mexican highlands between 1200 and 900 B.C. (Flannery and Marcus, 1994, Chap. 12).

Middle Preclassic (ca. $900-400$ B.C.)

A more comprehensive conjunctive approach is possible for the Middle Preclassic, because so many lines of evidence are available (settlement pattern data, superimposed floors, clear architecture, burials, caches, flora, and fauna). Furthermore, a number of sites with Middle Preclassic occupations have been excavated, such as Cuello (Andrews and Hammond, 1990; Hammond, 1991), El Pozito [sic] (Hester et al., 1991; Neivens, 1976), K'axob (McAnany, 1991, 1992), Colha (Hester and Shafer, 1984; Potter, 1991a, b; Shafer, 1991; Valdez, 1987), Kichpanha (Gibson, 1989), Lamanai (Pendergast, 1981), Pulltrouser Swamp (Turner and Harrison, 1983), Cahal Pech (Awe, 1992), Tikal (Coe, 1990; Laporte and Fialko, 1990), Uaxactún (Ricketson and Ricketson, 1937), Nakbe (Hansen, 1989, 1991), El Mirador (Demarest, 1984; Demarest and Fowler, 1984; Hansen, 1990; Matheny, 1980, 1986), Seibal (Sabloff, 1975; Willey, 1978), Altar de Sacrificios (Adams, 1971), Calakmul (Folan, 1985; Folan et al., 1994; Pincemin, 1989), 
Oxkintok (Rivera D., 1992), Dzibilchaltún (Andrews V, 1981; Andrews IV and Andrews V, 1980), and Komchen (Andrews V, 1981; Ringle and Andrews V, 1988, 1990).

As late as the Middle Preclassic, we still cannot show that the Maya of northern Belize had moved beyond the stage of egalitarian farmers living in autonomous villages. Villagers were buried beneath or near their houses, but not in segregated cemeteries or special tombs. For example, Middle Preclassic graves at Cuello were placed under house floors and in house platforms, and Robin and Hammond (1991, p. 225) note that throughout that period, males, females, and juveniles have comparable grave goods. We do not have as many Middle Preclassic burials for other sites; however, when the final reports from K'axob, Cahal Pech, and other sites are published, we will be in a much better position to compare populations at several Maya villages.

In some sites in northem Guatemala (in contrast to northern Belize), rank societies seem to be in evidence during much of the Preclassic. Beginning in the second half of the Middle Preclassic, some regions displayed relatively simple chiefdoms with a two-tiered settlement hierarchy and some evidence for ranking (principally inferred from burials). This two-tiered hierarchy seems to characterize certain subregions of northern Guatemala and northern Yucatán, implying that village autonomy had been lost in those areas. Sites such as Nakbe, El Mirador, and Calakmul may have been rank societies (Dahlin, 1984; Hansen, 1991; Folan et al., 1994; Matheny 1980), but we lack sufficient information on Middle Preclassic regional settlement patterns, political hierarchies, and differential burial treatment to document this fully.

Late Preclassic (ca. 400 B.C.-A.D. 250)

By Late Preclassic times, the three-tiered hierarchies characteristic of more advanced chiefdoms had appeared in many regions. For example, sites such as El Mirador, Calakmul, Tikal, Nakbe, and Komchen seem to have become the paramount centers of rather flamboyant chiefdoms. Although Sharer (1992) suggests that these might be early states, we still lack the necessary data on settlement patterns, four-tiered administrative hierarchies, palaces, and so forth. If such data are collected, we might be able to reclassify some of these Late Preclassic societies as states.

Late Preclassic temples were placed atop huge pyramids at centers such as El Mirador, Calakmul, Río Azul, Nakbe, Cerros, and Lamanai (Adams, 1990; Folan et al., 1994; Matheny, 1986; Robertson and Freidel, 1986). The huge pyramidal bases often had modeled, painted, and lime- 
plastered façades that depict oversized supernatural beings. For example, Calakmul's Late Preclassic Structure II (55 m high and $140 \times 140 \mathrm{~m}$ at its base) and El Mirador's "El Tigre" structure are two of the largest pyramids ever built in the Maya area. The ability to command extensive manpower to construct pyramids and causeways is impressive, but size alone is insufficient to show that statehood had been reached. Monk's Mound at Cahokia was built by a Mississippian chiefdom, as were the impressive pyramidal structures of Moundville.

The Late Preclassic was a time when caches became very common at places such as Uaxactún, Tikal, K'axob, Cuello, and Cerros. Many temples had dedicatory caches that contained stone "eccentrics," so labeled because of their unusual (ritual/symbolic) shapes. Although some were of local chert, others were of imported chert or obsidian. During the Late Preclassic there is evidence of full-time occupational specialization within a regional economic sphere, one in which chert tools manufactured at Colha were widely exchanged (Dockall and Shafer, 1993; McAnany, 1989c; McSwain, 1991; Shafer and Hester, 1983). This exchange network probably reflects trading partners linked by ties of kinship and fictive kin; in addition to the beautiful eccentrics, it is possible that perishable products were also exchanged. Many Colha eccentrics found their way into caches and burials at other sites, both near and distant.

Another Late Preclassic trend in the Lowland Maya area was the conversion of formerly residential areas into localities for public buildings (a transformation that can be seen elsewhere in Mesoamerica, such as the Valley of Oaxaca). For example, K'axob in northern Belize covers 84 ha, has 90 visible structures, with the majority arranged around open courts, and shows a long occupation extending from the Middle Preclassic to Terminal Classic. There McAnany $(1991,1992)$ has evidence to suggest that a Middle Preclassic residential area was transformed into a Late Preclassic sacred area with platforms and shrines, possibly for ancestor worship. During the Classic period a 4-m tall pyramid that covered the entire area was built.

Another exciting development of the last decade has been the increasing recovery of evidence for Late Preclassic raiding, captive taking, and mass burial of sacrificed victims. Such burials are now known from Late Preclassic Cuello (Gerhardt, 1988; Robin, 1989), the Salamá Valley (Sharer and Sedat, 1987), and Chalchuapa (Fowler, 1984), as well as from Early Classic Tikal (see below). At Cuello, many of the 103 Late Preclassic burials were from two mass burials (Mass Burial I had 32 individuals, and Mass Burial II had $12^{+}$males). In both mass burials, two principal occupants were placed in each grave first; then others were placed around them. Many of the added burials (nearly all male) appear to have been sacrificed 
or enterred as bundles (Robin and Hammond, 1991). Six carved bone tubes were placed in Mass Burial I (ca. 300 B.C.); four are noteworthy because they display the "mat motif" (pop symbol). This mat motif was widespread throughout the Mesoamerican highlands, having been used as a symbol of chiefly authority as far back as 1000 B.C. in the Valley of Oaxaca (Marcus, 1992a, p.304). The motif might have had the same chiefly implication at Cuello at 300 B.C. In later periods, after actual states had evolved, the mat symbol became an insignia of royalty among the Maya, Aztec, and Mixtec.

Preclassic raiding, captive taking, skeletal mutilation, and mass burials have emerged as themes for future Maya research. We need to know much more about the chiefly competition and cooperation that set the political stage for the transformation of Maya chiefdoms into states. Maya warfare may have increased and decreased in different periods at different sites, but it was clearly not an innovation of the Classic or Postclassic-a position once advocated by Morley (1946) and others.

Indeed, it now appears that warfare may have been a major factor in Becán's rise during the Late Preclassic (Webster, 1976, 1977) and in Rio Azul's rise during the Early Classic (Adams, 1990). Such warfare has often been invoked in the demise of Maya civilization, but too rarely mentioned as a factor in its rise (Marcus, 1992b).

Warfare (as well as economic and sociopolitical competition) may have been involved in the collapse of El Mirador, an early site virtually abandoned by A.D. 150. Cerros also appears to have been abandoned about this time, but the site across the bay from it-Santa Rita Corozalseems to have flourished after Cerros was abandoned, perhaps even because of the latter's abandonment.

Abandonment of centers between A.D. 100 and A.D. 250 may have been widespread, as some have suggested (Morley et al., 1983, p. 81); such abandonment is most evident in the Guatemalan Highlands and El Salvador. There, data from the site of Chalchuapa and others in the Zapotitán Valley have provided one explanation for an abandonment that endured for 200 years: with the eruption of the Ilopongo volcano during the summer of A.D. 175, central Salvadoran populations were displaced and trade ties were broken (Sharer and Sedat, 1987; Sheets, 1992; 1993, p.22). While this volcanic eruption may explain site abandonments in the southeastern Maya area, it seems quite insufficient to explain abandonments in areas more distant from Ilopongo, such as the drastic decline in population around Komchen in Northwest Yucatán between A.D. 100 and A.D. 600. Furthermore, a number of key sites such as Tikal, Calakmul, and Santa Rita Corozal show that many centers continued, apparently without interruption. This pattern of abandonment of some sites and regions and not others 
anticipates the cyclical declines and rises of other sites throughout the Classic period.

\section{Classic (A.D. 250-900)}

The Classic period is traditionally divided into two halves-an Early (A.D. 250-600) and Late (A.D. 600-900). The Late Classic has received more attention than any other period in the Maya archaeological sequence, primarily because it is so accessible and visible. The Late Classic saw peaks in both architectural activity (numbers of temples, palaces, stelae, ballcourts) and population (as inferred from the total numbers of sites and the density of housemounds at those sites). Such explosions in construction activity and population must have had antecedent causes; thus the Early Classic continues to loom as a crucial period for future research. The bad news is that the Early Classic-the principal period of Maya state formation-is poorly known at most sites. The good news is that the conjunctive approach can be effectively implemented in the Early Classic because many lines of information are available, including many newly discovered hieroglyphic texts.

In the Maya area, as in many parts of the ancient world, buildings that are clearly temples appear before buildings that are clearly palaces. It has been quite easy to find Maya temples and to document their evolution; they are tall and visible, and their pyramidal bases are often immense. In contrast, documenting the evolution of the Maya palace has been very difficult [but the $\mathrm{A}-\mathrm{V}$ sequence at Uaxactún is one nice example (see Smith, 1950)]. Unlike temples, palaces were usually broad and low, and rarely towered over a Maya city. Because of Sanders' (1974) cross-cultural study suggesting that most chiefs cannot summon sufficient manpower to build a palatial residence for their private use-while kings can-documenting the initial appearance of the palace has become an important matter for documenting the rise of the Maya state.

Evidence for the first appearance of the Maya state continues to be elusive. We need to be able to document the shift from a three-tiered settlement hierarchy (typical of chiefdoms and cacicazgos) to the four-tiered hierarchy typical of states elsewhere in the ancient world (Spencer, 1990; H. Wright, 1977; Wright and Johnson, 1975). While there have been woefully few systematic regional surveys of the type needed to show this shift, epigraphic evidence suggests that it had happened by A.D. 400-500 (Marcus, 1976). This is also the century when we can first document palaces, as at Tikal (Harrison, 1970). Current work beneath the Copán Acropolis suggests to Sharer'(personal communication, 1994) that the earliest palace 
complexes may have been constructed of adobe and timber. Future surveys and excavations might therefore push both the four-tiered hierarchy and the palace back to the start of the Early Classic.

One encouraging development of the last 15 years is that it now appears that the Maya state is amenable to the same methods used to study Old World states. In 1973 I predicted that Calakmul would turn out to be the capital of one of the largest Classic states. My prediction was based on four lines of evidence, two borrowed from the Old World.

First, Calakmul was the city most often mentioned by other Maya centers, a sure sign of importance based on Tobler and Wineberg's (1971) study of Cappadocian site mentionings. Second, the mentionings of Calakmul were most often by lower-order sites (such as a distant subordinate like Dos Pilas, whose ruler attended a Calakmul lord's inauguration) and less often by equals (such as Tikal). Third, Calakmul was one of the cities described as "the four on high" by the Copán ruler 18 Jog. Fourth, the secondary sites beneath Calakmul formed an almost perfect hexagonal lattice around it, much like the lattices that formed around important Mesopotamian cities like Eshnunna (Johnson, 1972, Fig. 3) and Warka (Johnson, 1975, Fig. 31).

While many Mayanists doubted that Calakmul was a capital in 1973 (indeed, some denied that the emblem glyph in question even belonged to Calakmul), William J. Folan was sufficiently convinced to begin a program of mapping and excavation at Calakmul. Twenty years later, there is no longer any doubt that Calakmul was the capital of one of the largest Classic Maya states. The success of this prediction should tell us that the Maya were not "unique" (see Trend II, below) and that many methods of studying Old World states can be applied to Mesoamerican states.

\section{Early Classic (A.D. 250-600)}

There are exciting Early Classic data from many sites, including Tikal, Río Azul, Calakmul, Copán, and Yaxuná (Freidel et al., 1992, 1993), including new information on warfare and political alliance.

Excavations at Tikal have revealed several Early Classic structures in the Mundo Perdido Complex and in Group 6C-XVI. Finds include Stela 39, numerous Early Classic burials, a ballcourt marker, and a series of temples and platforms arranged in an astronomical complex similar to those of Group E at Uaxactún and the Main Plaza at Calakmul (Fialko, 1987; Folan et al., 1994). The Mundo Perdido Complex was used from the Middle Preclassic (700/600 B.C.) to the Terminal Classic (A.D. 900), undergoing continuous alteration throughout Tikal's history. By ca. 500 B.C., a pyramid 


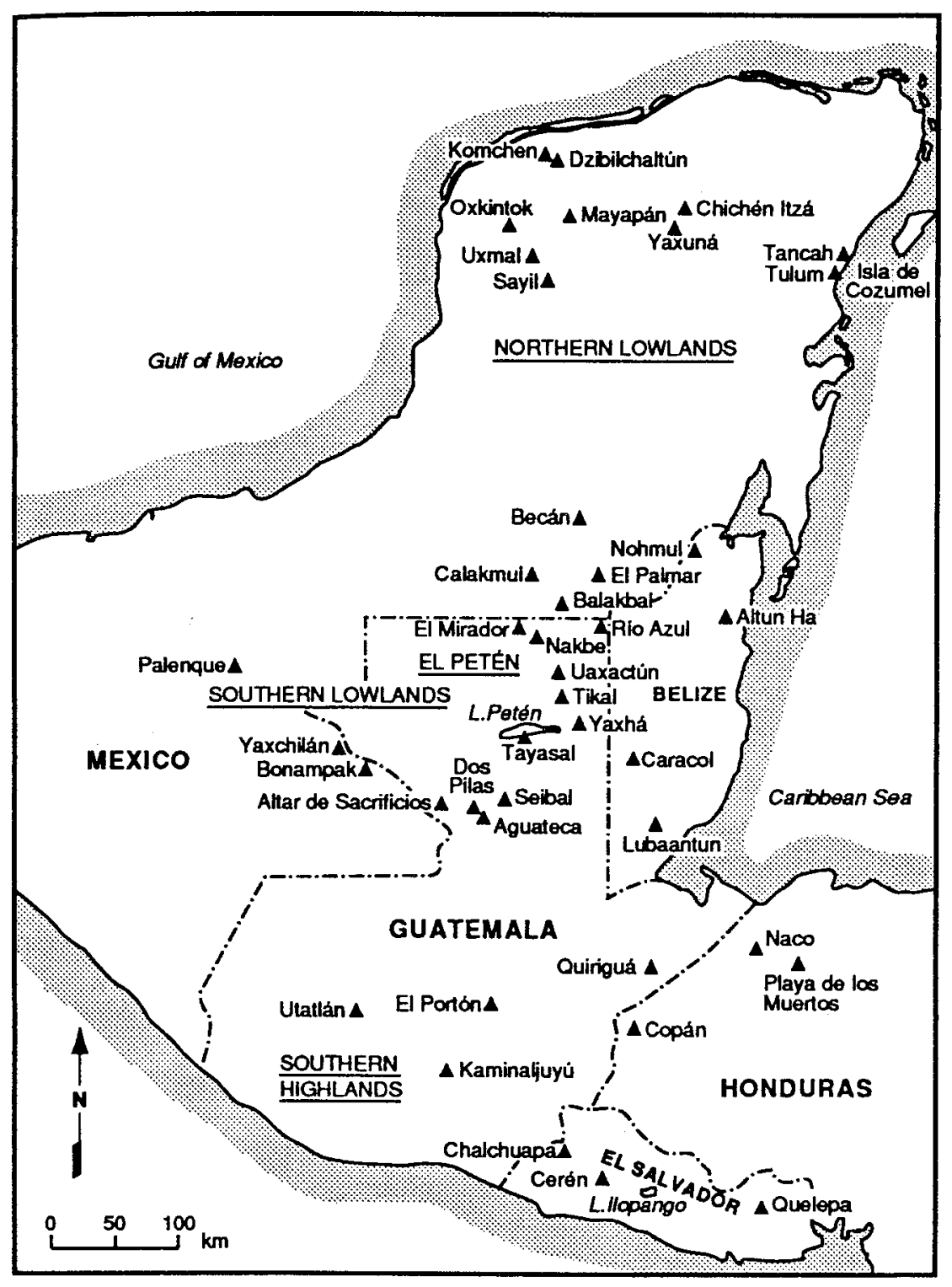

Fig. 3. Major sites in the Maya Lowlands and Highlands.

and platform had been constructed across from each other, defining an early plaza. By ca. A.D. 300 the area had a series of temples and platforms. 
One platform was constructed to cover a mass grave containing 16 or 17 individuals, evidently sacrificed to coincide with the dedication of Stela 29 (A.D. 292). This set of sacrificial victims is reminiscent of the earlier mass burials at Cuello and Chalchuapa.

Sometime between A.D. 300 and A.D. 350, a frieze of five nude and partially mutilated captives was modeled on Str. 5D-86-6 at Tikal (Laporte and Fialko, 1990). Similar bound captives are known from Río Azul at A.D. 380 (Adams, 1986, 1990). Such Early Classic depictions of bound captives supplement much earlier mass burials; together, they suggest that raiding and sacrifice continued to be important features of Maya society during the long transition from chiefdom to state (see below). Before A.D. 250, the North Acropois at Tikal had been the principal location for elite burials. Between A.D. 250 and A.D. 400, elite burials were placed in the Mundo Perdido Complex. After A.D. 400, elite burials were again situated in the North Acropolis. Laporte and Fialko (1990) take this change in the location of elite burials to reflect competition between at least two lineages-one (the Jaguar Paw lineage) in the Mundo Perdido Complex and the other (the Ma'Cuch lineage) in Group 6C-XVI. The Jaguar Paw lineage seems to have been dominant until A.D. 378, when a ruler of the Ma'Cuch lineage named Smoking Frog was inaugurated. Although there is considerable disagreement as to whether "Smoking Frog" was the Tikal ruler, a sibling of the ruler, or a usurper, "Smoking Frog" does seem to have controlled Uaxactún. This politically volatile period, with its evidence of links between the rulers of Tikal and Uaxactún, will continue to be the subject of conflicting interpretations because the texts are few in number; they are laconic; and there are several ways to "read between the glyphs" (Ayala F., 1987; Coggins, 1975; Marcus, 1974, 1992a; Mathews, 1985; Proskouriakoff, 1993; Schele and Freidel, 1990).

Although R. E. W. Adams' Río Azul Project is regional in scope (involving the survey of a large zone, and the mapping of 32 sites), most attention so far has focused on Río Azul itself, where excavations reveal that both the Late Preclassic and the Early Classic were major periods of occupation and construction. By A.D. 150, the east side of the river witnessed the construction of massive platforms running from Arroyo Negro to what became the center of Río Azul, a distance of about $5 \mathrm{~km}$. One of these platforms was $15 \mathrm{~m}$ high and supported one or more buildings; superstructures here and elsewhere were destroyed during the Early Classic, during the period when Tikal ( $71 \mathrm{~km}$ to the south) played a big role in Río Azul's history. About A.D. 385, according to a range of data pulled together by Adams (1990, p. 34), the Río Azul zone was conquered by Tikal. Following that conquest and the apparent execution of the local Río Azul elite (an event depicted on altars carved with hieroglyphic texts), the ruler of Tikal 
apparently placed members of his own ruling dynasty into positions of power at Río Azul.

Early Classic Río Azul had a highly nucleated population, estimated at 3500 persons, living in the site center. There is a lack of fit, however, between that relatively low population estimate and the vast amount of monumental architecture built during the Early Classic. That lack of fit led Adams (1990, p. 29) to suggest that Río Azul periodically imported large numbers of laborers to undertake major building projects. Significantly, this arrival of outside laborers would have occurred shortly after Río Azul was incorporated into the Tikal polity. Thus, from A.D. 390 to A.D. 530, enormous temples were built at Río Azul; some overlie tombs decorated with painted murals, one of which contains texts that may indicate that the tomb occupant was a son of the Tikal ruler. Río Azul was apparently abandoned between A.D. 530 and A.D. 600. Adams (1990, p. 37) argues that Río Azul was a secondary administrative center, a commercial center, and a "frontier site" located near the edge of the large regional state whose capital was Tikal. Conquest by Tikal (followed by incorporation into the Tikal regional state) was apparently a crucial element in Río Azul's development.

New Early Classic data have also come from Copán, where a sequence of 10 superimposed platforms, constructed between A.D. 400 and A.D. 500, has emerged deep inside the Late Classic Acropolis. Evidence of the origins and growth of Copán's temple complex and adjacent "palace complex" have been exposed by a series of tunnels beneath the Acropolis (Sharer et al., 1994). The earliest platform (A.D. 400-450), designated "Margarita," is the only one in the sequence that has an elaborate façade (Sharer et al., 1992) -in this case depicting Lightning, Storm, and other supernatural forces. Given Margarita's early date, Sharer (1993b) has suggested that the platform may be associated with Yax K'uk Mo', the "founder" of the Copán dynasty. A carved text on the summit of Margarita (dating to A.D. 437) bears this ruler's name and possibly that of his son, lending additional support to the claims of Yax K'uk Mo' and his descendants. Recent excavations below Margarita have located a huge tomb that might contain Yax K'uk Mo' himself, or his successor.

One of the most discussed new finds has been a stone monument from Caracol. Altar 21 (a ballcourt marker) was carved in A.D. 633 and bears a damaged hieroglyphic text. One phrase in that text has been interpreted as Caracol claims it conquered Tikal on May 1, A.D. 562 (A. Chase and D. Chase, 1987; Houston, 1987). However, as noted by Haviland (1991, p. 2), the actual meaning of the phrase remains ambiguous. Although the event glyph may indeed mean "raid" or "battle" (Marcus, 1976, pp. 130-140), the rest of the phrase does not include any information about a 
"victory," nor do we know what such a boast would entail. All that can be said is that the phrase mentions a battle with Tikal and that it was carved 70 years after the alleged battle took place-by which time few participants would have been alive to contradict it.

We now know that such claims of battle, often made long after the fact, were typical of former secondary centers who broke away from a major capital following a "war of independence" (Marcus, 1992a, pp. 428-430). In fact, Haviland (1991, p. 9) says that there is "an absence of evident Caracol influence at Tikal precisely when [Caracol's] Lord Water is supposed to have 'conquered' the city." Haviland stresses that such texts may be boasts, and that we must have follow-up archaeological evidence to evaluate the veracity of the claims and the impact of the events.

It is likely that many battles took place throughout the Preclassic and Classic, but remarkably few were recorded in texts. I suspect that only a small percentage of such battles actually led to the demise of a ruler or the abandonment of a site, but some did enable usurpers to take the throne following a gap in succession or allow some former dependencies to achieve independence, at least for a while.

Recent excavations at Calakmul have also added to our knowledge of the Early Classic. The newly discovered Stela 114 is the first Cycle 8 monument known from Calakmul; it extends the dynastic sequence back to A.D. 431 (Marcus, n.d.; Marcus and Folan, 1994a,b). Formerly, Calakmul's dynastic sequence began in A.D. 514, and the site of Balakbal was the most northerly site with a Cycle 8 stela.

A major fourth-century A.D. tomb has been excavated below Room 6 of Structure III at Calakmul, an imposing 12-room palace with three roof combs and large stucco façade masks (Folan et al., 1994). The tomb contained a male at least 30 years of age, lying on a woven mat supported by five dishes serving as a "bed." The most spectacular offerings were three jade mosaic masks-one for the man's face (170 pieces of jade), another on his chest (125 pieces), and the third for his belt (92 pieces). Similar mosaic masks are known from other cities-for example, in a Terminal Preclassic cache at El Portón and in Tikal's Burial 160 (ca. A.D. 527). Also found with the Calakmul burial were three pairs of jade earplugs, a jade ring, 32 jade beads (plain and carved), 8252 shell beads; several Spondylus and Oliva shells, a stingray spine; and a block of red pigment. Suspended as a group from the mask on the deceased's chest were three jade plaques incised with glyphs, similar to the trio of plaques worn by the ruler on Calakmul's Stela 43 (A.D. 514). Similar trios of plaques are shown suspended from belt masks on Tikal's Stela 31 (A.D. 445) and on the Leyden Plaque (A.D. 320). This Calakmul tomb may contain the remains of one 
of the earliest rulers to accede to office after the site became the capital of a state (Marcus, n.d.).

\section{Late Classic (A.D. 600-800)}

The Late Classic was characterized by recurrent cycles of consolidation (the pulling together of sites under the control of large capitals) and dissolution (the loss of some or all those sites through "wars of independence") (Marcus, 1976, 1992b). During the peak periods when capitals controlled multiple centers, they participated in extensive networks and far-flung alliances that served many ends-military, social, political, economic, and ritual. During the Late Classic, Tikal and Calakmul were capitals of the two most powerful states in the greater Petén; their "names" (emblem glyphs) appear more frequently in the texts of other sites than do any others (Marcus, 1974, 1987). There is good evidence for Tikal's and Calakmul's control of subordinates, as well as their meddling in the affairs of those subordinates (Marcus, 1976, 1988, 1993, n.d.). Flanking the Calakmul and Tikal states were the regional polities of Palenque and Yaxchilán (to the west) and Copán (to the southeast). Those five cities administered polities that varied in areal extent and provincial makeup over time (Marcus, 1993). New evidence shows that the political, economic, and religious hierarchies below these major centers were rarely isomorphic (Ball, 1993; Hester and Shafer, 1984; Marcus, 1983; McAnany, 1989a-c; Potter, 1993; Sabloff and Henderson, 1993; Shafer and Hester, 1983).

Even though the Late Classic Maya state had a four-tiered hierarchy (the upper three levels of which appear to have had administrative institutions), it is only the top two levels that have received significant research attention. Too little work has been done at third- and fourth-order sites, and too few excavations have been conducted on the residences of commoners (exceptions include Blake, 1985; Carmean, 1990; Fauvet-Berthelot, 1986; Gonlin, 1993; Hill, 1982; Webster and Gonlin, 1988; Wilk and Ashmore [eds.] 1988). Given that commoners' houses-represented by thousands of housemounds-constitute the majority of the residences at most sites, they have certainly not been uncovered in numbers commensurate with their abundance. Until this happens, our reconstructions of Maya life will remain biased and impoverished (Sabloff, 1983, 1990).

For some time, the scale and hierarchical complexity of Late Classic polities have been hot topics. Prior to 1973, many scholars considered Tikal to be the sole capital of the Maya Lowlands. Today everyone agrees that the region had more than one capital, but estimates vary from fewer than 
10 to over 100! Field archaeologists (Adams, 1990; Adams and Jones, 1981; Bove, 1981; Culbert et al., 1990; Folan et al., 1994; Marcus, 1973, 1983, 1993) see evidence for large regional states; a couple of epigraphers (Houston, 1993; Mathews, 1985); see every single site with an emblem glyph as autonomous. I see no evidence that any ancient state had the latter structure, but I do think that there were periods when secondary centers and noncontiguous provinces broke away from capitals and established their independence (Marcus, 1976, 1992a, b, 1993).

Similar disagreements characterize ancient Mesopotamia. There, field archaeologists tend to see larger polities than do some epigraphers (Henry Wright, personal communication, 1992). One reason is that a city's economic texts rarely emphasize its subordination to another center, whereas the settlement pattern data, the distribution of administrative artifacts, and the ceramic style zones often suggest that such subordination exists. Postgate (1992, p. 44) has recently presented a scheme for cyclic consolidation and dissolution in ancient Mesopotamia that parallels my own view of the buildup and breakdown of Maya states (Marcus, 1988, 1992b).

There were at least two ways a secondary or tertiary center could break away from a regional capital: through a "war of independence" or by allying itself with a powerful enemy of its capital. For example, Dos Pilas seems to have allied itself with Calakmul, an enemy of Tikal's, to gain independence from the latter (Folan et al., 1994; Marcus and Folan 1994b). In Maya states, warfare was both a mechanism by which powerful rulers could incorporate smaller and weaker polities into increasingly larger realms and a mechanism by which rebellious provinces could break away and establish their independence (Marcus, 1988, 1992a, b, 1993).

In states, as Webster (1993) has noted, warfare is serious business. We see this in murals from Mul-Chic, Chichén Itzá, and Bonampak, where military campaigns led to the capture of prisoners. Even large mural scenes showing scores of combatants, such as those in the Temple of the Jaguars and Temple of the Warriors at Chichén Itzá, probably cannot do justice to the hundreds or even thousands killed, resettled, or brought back as slaves. Moats, walls, or massive earthworks at sites like Becán, Tikal, Dos Pilas, and Punta de Chimino hint at the scale of Classic warfare and the large numbers of people involved. These new data suggest that we must reassess the role of warfare in our models of Maya state formation, state maintenance, and site abandonment (Demarest, 1992; Webster, 1993). Although war and military alliance were present in Early Classic times, they became increasingly frequent (or at least, were recorded more frequently in texts and art) during. the Late Classic. 
To assess the long-term impact of Late Classic warfare we need more regional surveys, such as those being done in the Copán Valley, Río AzulLa Milpa area, Calakmul zone, and Petexbatún region. Without the regional perspective that comes from systematically surveying hundreds of thousands of square kilometers, we will continue the unwise practice of extrapolating from one site to an entire region.

Ongoing surveys and excavations at sites located to the east of the Copán Valley are revealing in situ developments in elite architecture, administrative hierarchies, and craft production. Although this area is called the "Southeast Periphery" or "Maya Frontier," new work is forcing us to rethink those labels, and to consider these regions as having their own parallel evolutionary history (Henderson, 1987, 1992a,b; Joyce, 1986, 1991; Lange, 1992; Schortman, 1986, 1989; Schortman and Nakamura, 1992; Urban and Schortman, 1986).

\section{Terminal Classic to Early Postclassic (A.D. 800-1000)}

In the 1940s, Maya scholars believed in a three-part temporal sequence: first (1) a peaceful, theocratic "golden age" (A.D. 600-800), then (2) a mysterious "collapse" at A.D. 850, indicated in the southern Lowlands by the cessation of hieroglyphic texts on stelae, and finally (3) a post-A.D. 850 secular and militaristic resurgence in Yucatán. This scenario was based on three false assumptions: (1) that there were a uniform, static "Classic" society and a uniform, static "Postclassic" society, too different to be compared; (2) that the northern and southern Lowlands were occupied sequentially, with no temporal overlap; and (3) that the Classic Maya were peaceful, while the Postclassic Maya were bellicose.

Some of these views resulted from the myopic perspective mentioned above, whereby scholars extrapolated from one site to the entire southern Lowlands. From recent settlement pattern surveys, dirt archaeology, and ethnohistory, we have learned that there was no uniform Lowland "collapse" (Pendergast, 1985, 1986; D. Rice, 1986; P. Rice, 1986, 1987; P. Rice and D. Rice, 1985; Sabloff, 1992; Sabloff and Andrews, 1986; Sharer, 1982; Webster and Freter, 1990a, b). With Giles Healey's 1946 discovery of battle scenes in the Bonampak murals, the "peaceful" Maya were shown not to be so peaceful; and later, Proskouriakoff's studies $(1963,1964)$ of the Yaxchilán texts revealed that battles and warfare were prominent features of Late Classic society.

Most scholars now reject the old static models, instead emphasizing the volatile, dynamic nature of the Classic and Postclassic. They note that 
when Dos Pilas' political fortunes waned, Aguateca's rose. When Aguateca's fortunes waned, Seibal's rose, and so did those of Sayil and other Puuc sites in the north. When Altun Ha was abandoned, Lamanai flourished. When some Puuc sites were abandoned, Chichén Itzá had a renaissance. After Chichén Itzá's fall, Mayapán reached its peak. Finally, after Mayapán fell, Santa Rita Corozal, Tipu, Topoxté, Macanché, Cozumel, Tulum, Tancah, and Naco continued.

Thus there was no single, monolithic "Maya collapse." Instead, there were many peaks and many troughs between A.D. 1 and A.D. 1500, oscillations that followed one another continuously throughout the Late Preclassic and into the Classic and Postclassic (Marcus, 1993). We would not have detected such cyclic processes if we had maintained our old notions that the Classic and Postclassic societies were completely different from each other and that the northern and southern Lowlands were too different to be compared.

Today a new question is being asked: "Was there or wasn't there a collapse?" The quickest answer is, "It depends on the site." As a result of recent fieldwork, we have at least three possible scenarios for the Maya collapse, each based on data from a different region. The three scenarios are that (1) there was no widespread collapse - that is, settlement continued at some sites, while others were abandoned; (2) there was a widespread collapse, but it was gradual; and (3) there was a widespread collapse, and it was abrupt and violent.

Data supporting the first scenario come from several sites. At Lamanai in Belize, Pendergast $(1981,1985)$ has evidence of continuous occupation from Middle Preclassic times to A.D. 1675. Pendergast (1986, p. 226) argues that

Lamanai could scarcely have remained a viable community in a vacuum created by collapse of political and social organization at neighboring Lowland centers, with the accompanying dissolution of intersite networks; it is therefore likely that the pattern of events at the site was repeated, at least in its main aspects, elsewhere in the area.

Other Belize sites show a Terminal Classic and Early Postclassic occupation, for example, Nohmul (Hammond, 1985; Pyburn, 1987, 1989, 1990) and La Milpa (Tourtellot et al., 1993). Additional evidence for Classic-Postclassic continuity is available from Topoxté, Macanché Island, and other sites (Bullard, 1970, 1973; D. Rice and P. Rice, 1981; P. Rice, 1987).

Data that may support the scenario of a gradual collapse come from the Copán Valley, where an argument for Classic-Postclassic continuity has been made by some (Webster et al., 1993; Webster and Freter, 1990a,b); others, however, argue for a more abrupt collapse and note the absence of Postclassic pottery (Braswell, 1992; Fash and Sharer, 1991). Webster et 
al. (1992, pp. 192-193) argue for a protracted disintegration of the Copán polity (A.D. 800-1250), owing largely to environmental degradation and attendant economic and political disruptions, but with $29 \%$ of the population still present at A.D. 1050.

\begin{abstract}
Although environmental degradation and poor nutrition and health, along with attendant political problems, are the obvious keys to the decline of the Copan polity, such fundamentally ecological problems cannot explain the very low levels of population after about A.D. 1050. There was enough fertile alluvial bottomland to feed a stable population of some thousands of people. Population loss probably was caused not only by high mortality and low fertility, but by emigration as well, as people left Copan for more attractive regions.
\end{abstract}

In contrast to the notion of a gradual collapse due to environmental degradation, the staff of the Petexbatún project favor an abrupt collapse triggered by warfare. Demarest and his colleagues suggest that a large polity, headed by the site of Dos Pilas, expanded its territory by incorporating subordinate sites through military conquest and marriage alliance (Demarest, 1992). In A.D. 761, according to their interpretation of the hieroglyphic texts, there was a major battle that led to the Dos Pilas ruler being deposed. Inhabitants stayed on for a while, hastily removing stones from temples and palaces to build a "siege village" of densely packed, low house platforms inside concentric walls in what had been the site's main plaza. Other sites in the vicinity built walls, palisades, terraces, and moats-for example, at the island fortress of Punta de Chimino and the blufftop stronghold of Aguateca, where many kilometers of defensive walls were constructed. When Dos Pilas' control of its polity ended, intersite warfare escalated enormously (Demarest, personal communication, 1994). The entire region, however, was not abandoned; nearby Seibal became a regional capital during the Terminal Classic and Early Postclassic periods. Seibal enjoyed a renaissance (possibly under the "foreign hegemony" of Chontal or Putún Maya), and the new Seibal ruler commissioned the construction of public buildings and stelae. Although warfare has been implicated in the collapse of Dos Pilas, warfare at Seibal (followed by foreign control) has been considered a factor in Seibal's florescence (Sabloff, 1975; Sabloff and Willey, 1967; Smith, 1982).

While Seibal flourished in the south between A.D. 850 and A.D. 950 , Chichén Itzá evidently emerged as the capital of a large state in the north. What is not clear is the size of the Chichén Itzá state, its duration, or its relationship to sites such as Uxmal, Cobá, and Ek Balam. Some scholars argue that Chichén Itzá, Uxmal, and Cobá were coeval capitals for a time (Dunning and Kowalski, 1994; Robles and Andrews, 1986), while others argue that Uxmal may have been a secondary center of Chichén Itzá's and 
that the latter site rose to prominence by uniting numerous provinces into a "joint government" or mul tepal (Marcus 1989, 1993; Morley, 1946; Schele and Freidel 1990). Although recent work (Andrews and Robles, 1985; Dunning, 1992; Dunning and Kowalski, 1994; Krochock, 1988; Lincoln, 1986; Ringle et al., 1991) in northern Yucatán has added abundant data, we still lack sufficient information to establish political and administrative hierarchies.

Postclassic (A.D. 900-1500)

During the decades when the Postclassic period was receiving a lot of attention in the northern Lowlands, most scholars neglected that period in the southern Lowlands. Fortunately, things have been changing in the south. Bullard's work at Topoxté Island in 1960 (Bullard, 1970, 1973) and at Macanché Island in 1968 (P. Rice, 1987) laid the groundwork for important regional surveys and excavations by Prudence Rice and Don Rice during the 1970s (D. Rice, 1986; P. Rice, 1986). Recently Rice, Rice, and G. Jones began a new project in the same area, both to document settlement patterns for Postclassic and Historic times and to evaluate the degree of fit between archaeology and ethnohistory. Additional work on the Postclassic of the southern Lowlands has been completed by others (A. Chase, 1976, 1982, 1985, 1990; D. Chase, 1985; G. Jones et al., 1981). Farther to the north, new work on the Terminal Classic and Postclassic includes that by A. Andrews et al. (1988, 1989), Ball (1985), Barrera R. (1985), Dunning (1992), Harrison (1979), Killion et al. (1989), Lincoln (1986), Miller (1982, 1985), Sabloff and Tourtellot (1991, 1992), and Tourtellot and Sabloff (1989), among others.

Postclassic populations were concentrated near bodies of water such as rivers, lakes, cenotes, and oceans. Communities such as Tipu (at Negroman in western Belize), Lamanai (near Indian Church in northern Belize), and Santa Rita Corozal ( $45 \mathrm{~km}$ north of Lamanai) have been under study. Some sites of this era enjoyed a Postclassic heyday; at Lamanai it appears that Spanish material culture was never more than a thin overlay (Graham et al., 1989, p. 1258). After the Spaniards arrived, Lamanai became a reducción, or was a Colonial community of Indians, while Tipu was an independent, stable center. The Spaniards lost their hold on the Maya in Belize during the A.D. 1638 rebellion, when the Maya became independent again after 70 years of Spanish authority.

Although Santa Rita Corozal has been occupied from Middle Preclassic times to today (D. Chase and A. Chase, 1986), one of its peaks came in the Postclassic period when it was a port of trade. Santa Rita out- 
lasted Mayapán after the latter's abandonment in A.D. 1450 and, evidently, became the capital of the Chetumal polity, which covered ca. $6000 \mathrm{~km}^{2}$. One of the major contributions of the Santa Rita Project has been its effective use of the Direct Historic Approach. Diane Chase (1985) has argued for continuity in some religious practices and beliefs from Classic to Postclassic to Historic times (see below).

\section{TREND II. THE DEMISE OF MAYA "UNIQUENESS"}

Generalists like Kirchhoff (1943), Swadesh (1967), and others of their generation unhesitatingly included the Maya as part of Mesoamerica. Despite this, over the years many Mayanists have persisted in treating the Maya as "unique." Years ago William Duncan Strong (1947, p. 645) criticized this approach in his review of S. G. Morley's 1946 book The Ancient Maya: "The 'Glory that was Maya' is well portrayed ..., but the mahogany frame which isolates it from the rest of native New World civilization seems unnaturally black and solid."

Recently there have been encouraging signs that we may be moving away from the notion that the Maya were "unique." Now we must take care to avoid the other extreme, that of asserting that the Maya were "identical to the rest of Mesoamerica." We need to establish exactly what the Maya shared, and what they did not share, with the rest of Mesoamerica. For example, we should be skeptical of those who impose Aztec (and other non-Maya) models on the Maya. And within the Maya area, we should be skeptical of those who impose Postclassic Highland beliefs on the Classic Lowland Maya.

Although we know that there was significant diversity within the Maya Highlands before the Spaniards arrived, many scholars seem comfortable in using a single book, the Popol Vuh-produced by the Quiché after A.D. 1560 at Utatlán - to reconstruct Lowland Maya cosmology from Preclassic times onward. The Popol Vuh provides us with the official view of Utatlán (Santa Cruz del Quiché) as seen by its rulers (Carmack, 1981; Edmonson, 1971). Such "official views" varied from town to town in the Highlands. Many Postclassic towns in the Guatemalan Highlands and in the Yucatec Lowlands kept "books" or codices, each conveying a local version of its history and myths. Even the highland neighbors of the Quiché, such as the Cakchiquel and Kanhobal, had their own origin myths. What is more, we know that the Popol Vuh contains Nahuatl and Spanish concepts (Carmack, 1981; Nicholson, 1957; Recinos, 1950).

Is it wise to assume that the Quiché represent all Maya? Is it wise to assume that the Quiché were unaffected by their contacts with the 
Putún/Chontal, Toltec, Aztec, and Spaniards? When we uncritically project Highland Quiché myths of A.D. 1560 into the Classic Lowlands, or search for characters like the "Hero Twins" on Preclassic vessels, are we not preventing ourselves from discovering how Maya beliefs evolved over thousands of years?

I do not mean to imply that we should not make use of the myths in the Popol Vuh; I merely suggest that we should be leery of using it as some people have, as a kind of Rosetta Stone for understanding the Preclassic and Classic Lowlands. There are some scenes painted on Maya pottery that have no counterpart in the Popol Vuh and other scenes that are actually at odds with myths given in the Popol Vuh (Cohodas, 1989). As noted by Carmack (1981), the Popol Vuh contains non-Maya (indeed, non-Indian) features. Carmack therefore suggests that we should take the Quiché as a specific case of cultural evolution and proceed to document changes throughout their history, using the Popol Vuh and other documents in a kind of Direct Historic Approach. This would allow us to compare Quiché cultural evolution to other groups within the Highlands and, eventually, to those in the Lowlands.

One of our long-term goals should be to discover how the Maya of the Highlands and Lowlands diverged over time from their common ancestors (Vogt, 1964a). In our rush to see the Maya as unique, we have underestimated such divergence. Just explaining the heterogeneity of Highland Maya groups could keep scholars busy for decades, since the Highlands have 20-26 language groups, while the Lowlands have only 2 (Cholan and Yucatecan). This could imply more continuity within the Lowlands than the Highlands, although-as we have seen-the label "Maya" can mask a great deal of diversity (Sharer, 1991). In speaking only of Highland Tzotzil, Vogt (1964b, p. 193) reminds us that "the bulk of the evidence collected by the various investigators in Chiapas recently indicates that there is not only significant variation from one Tzotzil municipio to the next, but that municipios themselves manifest important internal variations." We now know that earlier Mayanists, forced to generalize from the few sites that had been excavated, underestimated the magnitude of heterogeneity and cyclic change in the Lowlands. With huge increments in our database, we now can document significant differences within the Lowlands, within the Highlands, and between Highlands and Lowlands.

Some scholars thus swing between emphasizing Maya "uniqueness" and using Nahuatlized Highland documents to explain the Preclassic and Classic Maya. A more useful task would be to isolate what the Maya share with all Mesoamericans (either as a legacy of the earliest inhabitants of 
the area or through borrowing from non-Maya populations) and in what ways they differ.

\section{TREND III. THE MAYA AS A CASE STUDY IN CULTURAL EVOLUTION}

Evon Vogt (1964a) was the first to advocate the application of the "Genetic Model" (now called the "Phylogenetic Model") to the Maya. Vogt and Ruz Lhuillier (1964) were interested in understanding how the "protoMaya" diverged from their common ancestors, who were believed to have migrated from a home base in the northwest highlands of Guatemala at ca. 4000 B.C. In spite of the fact that this model has been applied to other peoples of Mesoamerica, such as the Zapotec and Mixtec (Flannery and Marcus, 1983), Mayanists have been slow to embrace it. This is not surprising, since processual archaeology and the conjunctive approach were also late in reaching the Maya area. Exceptions to this assessment include work at some Postclassic sites, such as Utatlán and Mayapán, where ethnohistory and archaeology have complemented each other.

One reason why these frameworks were not fully embraced was the aforementioned notion that the Maya were unique. Given this view, many scholars decided not to look for general processes and regularities in the evolution of the Maya. Today, however, an increasing number of scholars are interested in model building, and in comparing the Maya to other major civilizations. Unfortunately, many Mayanists have had a problem selecting appropriate ethnographic analogies for the Maya. Their search has been overly eclectic, when it should have been focused on societies that are truly comparable and on the same level of sociopolitical integration.

To reconstruct the Maya state, scholars have tried an enormous range of approaches: feudal models, Thiessen polygon polities, pulsating galactic polities, theatre states, segmentary states, peer polities, and so on. I have commented on some of these approaches already (Marcus, 1983, 1993) and discuss an additional two here.

Peer polity and segmentary state models are inappropriate analogies to the Classic Maya state, since both were designed to characterize prestate societies. As Renfrew and Cherry (1986, p.viii) make clear, the idea of "peer polities" was designed to model chiefly interaction at the prestate level; they were trying to model the ways that chiefdoms on different islands in the Aegean interacted prior to the emergence of the state. In such a model, the state eventually arises when one chiefdom becomes so powerful that it begins to dominate and annex neighboring polities, creating a new hierarchical level by reducing its neighbors to provinces within its much 
larger territory. Thus the "peer polity" model is not appropriate for the Maya of A.D. 600-800, unless one believes that the Late Classic Maya had still not moved beyond a chiefdom level. I doubt that many archaeologists and epigraphers believe that. I doubt that many, for example, would contend that eighth-century Bonampak was an equal, or "peer," of Yaxchilán; or that Río Azul, Jimbal, and Ixtutz were "peers" of Tikal; or that Oxpemul, Xamantún, El Palmar, and La Muñeca were "peers" of Calakmul.

As for segmentary state models, although much in vogue nowadays, they too are inappropriate for understanding the Classic Maya because they, like peer polity models, were designed to deal with prestate societies (Dirks, 1993; Southall, 1956, 1988; Yoffee, 1993). Furthermore, evidence for segmentary lineages among the Maya is lacking (D. Chase and A. Chase, 1992, pp.307-310; Hill and Monaghan, 1987; Kuper, 1982). The term "segmentary state" originated when Southall, working among the Alur of East Africa, was searching for an intermediate category to fill the gap between "the unitary state" and the "acephalous societies" studied by Fortes and Evans-Pritchard (1940). Although Southall (1991, p. 91) proposed the term "segmentary state," he has recently rethought it and explained: "Although I called it [the Alur] a segmentary state, it was hardly a state, hardly a two class society, and it could not prevent secession." Today most regard the Alur as a type of village society, perhaps comparable to the Middle Preclassic Maya but not remotely comparable to Classic Maya states. As noted by Diane Chase and Arlen Chase (1992), the Late Classic Maya actually fit Southall's "unitary state" model much better than his "segmentary state model."

If peer polities and segmentary societies are inappropriate models for Precolumbian states, where should we find our models for the Lowland Classic Maya state? Two possibilities are (1) other societies that are at the state level and (2) 16th-century eyewitness accounts of the Lowland Maya themselves. Both sources are rich, and neither has been fully exploited. Cautious, well-reasoned use of ethnohistoric data has become commonplace elsewhere in Mesoamerica. Although some scholars only feel comfortable using ethnohistoric accounts to gain insight into the Postclassic period, such data can be used to construct models that, in turn, can be tested against Classic period data to determine the degree of fit. While it seems obvious that ethnohistoric accounts are most relevant to the Postclassic, it does not follow that they have no relevance to the Classic period. We need to be very careful in peeling back the Spanish and Postclassic layers to determine a model's degree of fit with earlier eras.

Ironically, some epigraphers who object to the use of ethnohistoric data to understand the Classic Maya think nothing of using 16th- and 17thcentury vocabulary lists to decide how Classic hieroglyphs were pronounced 
and used. The fact is that Colonial vocabulary lists of Yucatec words have proved remarkably useful for studying Classic inscriptions that were probably written in Chol (Bricker, 1986; Lounsbury, 1973, 1989). For example, titles such as ahau ("ruler") and batab ("local lord") are known both from Colonial records and from eighth-century A.D. hieroglyphic texts. Epigraphers have assumed that these terms retained their specific meaning for more than a millennium; is it unreasonable to suspect that the hierarchical political system in which those terms were embedded might also be relevant to the eighth century?

If 16th-century Yucatec is considered appropriate to aid us in understanding offices and institutions mentioned in eighth-century texts, so is the political matrix in which those offices and institutions were embedded. Indeed, one might argue that they are much more appropriate than Aegean chiefdoms or the Alur of Africa.

We can draw important inferences about the sociopolitical milieu that produced Classic Maya titles. Inherent in the 16th-century terms for "ruler," "subordinate lord," and "local lord" is the very political hierarchy that settlement pattern analysis shows us for the Classic Maya states of the 8th century (Adams and Jones, 1981; A. Chase, et al., 1991; Culbert and Rice, 1991). From 16th-century Yucatec records and 17th-century Petén accounts we know that the ahau, who ruled a very large regional state, also referred to himself as the batab of his own town. Thus the ahau simultaneously administered three nested territories-batabil, cuchcabal, and ahaulil-comprising the "township," "provincial jurisdiction," and "state belonging to the ruler."

The fact that we can recognize the terms for different levels of rulers in 8th-century hieroglyphic texts suggests the same general hierarchy of rulers, and of settlements, seen both in our systematic regional surveys and in 16th-century Yucatán. All states display hierarchy, and if the Classic Maya reached the state level, they certainly had it. It is inconsistent to identify terms as ahau, batab, sahal/cahal, and so forth in Classic texts and then argue that all Maya towns and lords were autonomous. The Late Classic texts reveal well-developed hierarchies as well as dynamic polities, such as Calakmul, that expanded by incorporating contiguous and noncontiguous territories (Marcus 1988, 1992b).

\section{Value of the Direct Historic Approach}

With caution, ethnohistoric documents can be used to understand earlier periods; such methodology is called the Direct Historic Approach (Parker, 1922; Strong, 1933,1935; Wedel, 1938). The challenge is in discov- 
ering what has changed and what has continued. Ethnographic analogy can help, but only if Mayanists compare states to states, not states to chiefdoms (Sabloff, 1989, Chap. 10).

Since over 4 million Maya speakers survive today, and there are abundant ethnographic and ethnohistoric data, the Maya area is eminently suitable for application of the Direct Historical Approach. As I have suggested, such an approach need not focus exclusively on continuities; previous applications of the Direct Historic Approach have also emphasized the changes that took place over time (Marcus and Flannery, 1994; Strong, 1933; Wedel, 1938). This attention to change is important, because we know that Maya society witnessed profound changes between 10,000 and 1000 B.C., and again between 1000 B.C. and A.D. 1000. Here I am referring not just to changes in social and political complexity, but also to those facets of culture assumed to be "conservative" or "static," such as religion, ritual, and cosmology.

Obviously, the Direct Historic Approach is most defensible when one compares Lowland Maya ethnohistory to Lowland Maya archaeological sites and Highland ethnohistory to Highland Maya sites. Good examples of the Direct Historic Approach include Carmack's (1981) work with the Quiché, Diane Chase's $(1981,1985)$ work at Santa Rita Corozal, William Fowler's (1989) study of the Pipil-Nicarao, David Freidel and Jeremy Sabloff's (1984) work on Cozumel, Elizabeth Graham and co-workers' (1985) work at Tipu, Grant Jones and co-workers' (1981) work in the Petén, and Pollock and co-workers' (1962) work at Mayapán.

\section{WHERE WE WERE AND WHERE WE ARE}

During the 1970 s and 1980 s at least a few scholars challenged themselves and their colleagues to develop better research designs, carry out more work on the Paleoindian and Preclassic eras, and undertake more field projects to address such topics as diet, subsistence, demography, households, craft production, and the lifeways of commoners. They argued that it was time to stop characterizing Maya society as a whole from royal tombs, temples, and carved stones.

Have their appeals been answered? Partially. There is indeed new attention being devoted to the lives of commoners, to households, to subsistence, and to demography. Nevertheless, it is also clear that a great many Mayanists are still locked in competition for the biggest royal tomb.

The old patterns of focusing on the city rather than its antecedents, studying regional capitals rather than their lower-order centers, and focusing on stratification rather than the origins of ranking have been tough to 
discard. But there are new trends. Some projects are gradually integrating more lines of evidence from more levels of society, and those multiple lines of evidence are providing a richer picture of the Maya.

After years of struggling with the notion that the Classic Maya were unique, we seem at last poised to admit that the Maya were similar to other Mesoamerican states. They used warfare and strategic marriage alliance to acquire manpower and territory, they manipulated royal genealogies, they usurped offices to which they were not really in line, and they exacted tribute and labor from commoners (Marcus, 1988, 1992a; Webster, 1993). But comparing the Maya to other states is still so new to most Mayanists that many are confused about which societies to compare them tohence the inappropriate comparisons to segmentary societies like the Alur and Aegean chiefdoms like those of the Renfrew-Cherry "peer polity" model.

Much remains to be done in the Maya region: working out the stratigraphic sequence for the Paleoindian and Archaic; the origins of village life (including the discovery of a true Early Preclassic); the origins of ranking; the earliest appearance of the palace which heralds the rise of kingship; the mechanisms that prompted cycles of political expansion and contraction during the Classic; the political and economic demise of different regions of the Lowlands; and the reasons why certain regions endured (or even peaked) during the Postclassic while others did not. Good Maya archaeology will bring to light not merely what is unique and exotic about the Maya, but also what they shared with every other ancient civilization (Trigger, 1993).

\section{ACKNOWLEDGMENTS}

I thank R. E. W. Adams, Wendy Ashmore, Jaime Awe, Cassandra Bill, James Brady, Geoff Braswell, Arlen Chase, Diane Chase, Arthur Demarest, Barb Fash, Bill Fash, Willie Folan, Dave Freidel, Norman Hammond, Peter Harrison, Bill Haviland, Rosemary Joyce, Richard Leventhal, Mike Love, Linda Manzanilla, Tricia McAnany, Heather McKillop, Hattula Moholy-Nagy, Lorenzo Ochoa, David Pendergast, Don Rice, Bill Ringle, Ed Schortman, Payson Sheets, Pat Urban, Fred Valdez, and Dave Webster for supplying me with books, papers, half-written grant proposals, and much encouragement. Very special thanks go also to Gary Feinman, Jerry Sabloff, Bob Sharer, Will Andrews, John Henderson, Mary Pohl, Tom Hester, and Harry Shafer for their many useful comments on this paper. I tried to follow their advice using the space allotted, but I soon discovered I would 
need to double the length of this paper to cover all the topics they suggested.

\section{REFERENCES CITED}

Adams, R. E. W. (1971). The Ceramics of Altar de Sacrificios, Papers of the Peabody Museum, Harvard University, Cambridge, MA, Vol. 63, No. 1.

Adams, R. E. W. (1986). Rio Azul: Lost city of the Maya. National Geographic 169: 420-451. Adams, R. E. W. (1990). Archaeological research at the lowland Maya city of Río Azul. Latin American Antiquity 1: 23-41.

Adams, R. E. W., and Jones, R. (1981). Spatial patterns and regional growth among Classic Maya cities. American Antiquity 46: 301-322.

Andrews, A. P., and Robles, F. (1985). Chichen Itza and Coba: An Itza-Maya standoff in Early Postclassic Yucatan. In Chase, A. F., and Rice, P. M. (eds. ), The Lowland Maya Postclassic, University of Texas Press, Austin, pp. 62-72.

Andrews, A. P., Gallareta, T., Robles, F., Cobos, R., and Cervera, P. (1988). Isla Cerritos: An Itza trading port on the north coast of Yucatan, Mexico. National Geographic Research 4: $196-207$.

Andrews, A. P., Asaro, F., Michel, H. V., Stross, F. H., and Cervera, P. (1989). The obsidian trade at Isla Cerritos, Yucatan, Mexico. Joumal of Field Archaeology 16: 355-363.

Andrews, E. W., IV, and Andrews, E. W., V (1980). Excavations at Dzibilchaltun, Yucatan, Mexico, Middle American Research Institute Publication 48, Tulane University, New Orleans.

Andrews, E. W., V (1981). Dzibilchaltun. In Sabloff, J. A. (ed.), Archaeology, Vol. 1, Supplement to the Handbook of Middle American Indians, University of Texas Press, Austin, pp. 313-341.

Andrews, E. W., V, and Hammond, N. (1990). Redefinition of the Swasey phase at Cuello, Belize. American Antiquity 55: 570-584.

Awe, J. J. (1992). Dawn in the Land Between the Rivers: Formative Occupation at Cahal Pech, Belize and its Implications for Preclassic Developments in the Maya Lowlands, Ph.D. dissertation, Institute of Archaeology, University of London, London.

Ayala F., M. (1987). La estela 39 de Tikal, Mundo Perdido. Memorias del Primer Coloquio Internacional de Mayistas, UNAM, Mexico, pp. 599-654.

Ball, J. W. (1985). The Postclassic that wasn't: The thirteenth- through seventeenth-century archaeology of central eastern Campeche, Mexico. In Chase, A. F., and Rice, P. M. (eds.), The Lowland Maya Postclassic, University of Texas Press, Austin, pp. 73-84.

Ball, J. W. (1993). Pottery, potters, palaces, and polities: Some socioeconomic and political implications of Late Classic Maya ceramic industries. In Sabloff, J. A, and Henderson, J. S. (eds.), Lowland Maya Civilization in the Eighth Century A. D., Dumbarton Oaks, Washington, D. C., pp. 243-272.

Barrera R., A. (1985). Littoral-marine economy at Tulum, Quintana Roo, Mexico. In Chase, A. F., and Rice, P. M. (eds.), The Lowland Maya Postclassic, University of Texas Press, Austin, pp. 50-61.

Bird, J. B., and Cooke, R. (1978). The occurrence in Panama of two types of Paleo-indian projectile points. In Bryan, A. L. (ed.), Early Man in America from a Circum-Pacific Perspective, Occasional Papers No. 1, Department of Anthropology, University of Alberta, Edmonton, pp. 263-272.

Blake, T. M. (1985). Canajaste, Ph. D. dissertation, University of Michigan, Ann Arbor.

Bove, F. J. (1981). Trend surface analysis and the lowland Classic Maya collapse. American Antiquity 46: $93-112$.

Braswell, G. A. (1992). Obsidian-hydration dating, the Coner phase, and revisionist chronology at Copán, Honduras. Latin American Antiquity 3: 130-147. 
Bricker, V. R. (1986). A Grammar of Mayan Hieroglyphs, Middle American Research Institute Publication 56, Tulane University, New Orleans.

Brown, K. L. (1980). A brief report on Paleoindian-Archaic occupation in the Quiche Basin, Guatemala. American Antiquity 45: 313-324.

Bullard, W. R. (1970). Topoxte: A Postclassic Maya site in Peten, Guatemala. In Bullard, W. R. (ed.), Monographs and Papers in Maya Archaeology, Papers of the Peabody Museum of Archaeology and Ethnology, No. 61, Harvard University, Cambridge, pp. 245-308.

Bullard, W. R. (1973). Postclassic culture in central Peten and adjacent British Honduras. In Culbert, T. P. (ed.), The Classic Maya Collapse, University of New Mexico Press, Albuquerque, pp. 221-242.

Carmack, R. M. (1981). The Quiché Mayas of Utatlan: The Evolution of a Highland Guatemala Kingdom, University of Oklahoma Press, Norman.

Carmack, R. M., and Weeks, J. M. (1981). The archaeology and ethnohistory of Utatlan: A conjunctive approach. American Antiquity 46: 323-341.

Carmean, K. (1990). The Ancient Households of Sayil: A Study of Wealth in Terminal Classic Maya Society, Ph.D. dissertation, Dept. of Anthropology, University of Pittsburgh, Pittsburgh.

Chase, A. F. (1976). Topoxte and Tayasal: Ethnohistory in archaeology. American Antiquity 41: $154-167$.

Chase, A. F. (1982). Con manos arriba: Tayasal and archaeology. American Antiquity 47: $167-171$.

Chase, A. F. (1985). Postclassic Peten interaction spheres: The view from Tayasal. In Chase, A. F., and Rice, P. M. (eds.), The Lowland Maya Postclassic, University of Texas Press, Austin, pp. 184-205.

Chase, A. F. (1990). Maya archaeology and population estimates in the Tayasal-Paxcaman zone, Peten, Guatemala. In Culbert, T. P., and Rice, D. S. (eds.), Precolumbian Population History in the Maya Lowlands, University of New Mexico Press, Albuquerque, pp. 149-165.

Chase, A. F., and Chase, D. Z. (1987). Investigations at the Classic Maya City of Caracol, Belize: 1985-1987, Pre-Columbian Art Research Institute Monograph 3, San Francisco.

Chase, A. F., Grube, N., and Chase, D. Z. (1991). Three Terminal Classic monuments from Caracol, Belize. Research Reports on Ancient Maya Writing, No. 36, Center for Maya Research, Washington, D. C.

Chase, D. Z. (1981). The Maya Postclassic at Santa Rita Corozal. Archaeology 34: 25-33.

Chase, D. Z. (1985). Ganned but not forgotten: Late Postclassic archaeology and ritual at Santa Rita Corozal, Belize. In Chase, A. F., and Rice, P. (eds.), The Lowland Maya Postclassic, University of Texas Press, Austin, pp. 104-125.

Chase, D. Z., and Chase, A. F. (1986). Offerings to the Gods: Maya Archaeology at Santa Rita Corozal, University of Central Florida, Orlando.

Chase, D. Z., and Chase, A. F. (1992). An archaeological assessment of Mesoamerican elites. In Chase, D. Z., and Chase, A. F. (eds.), Mesoamerican Elites, University of Oklahoma Press, Norman, pp. 303-317.

Coe, W. R. (1990). Excavations in the North Acropolis, North Terrace, and Great Plaza of Tikal, Tikal Report 14, University Museum Monograph 61, University of Pennsylvania, Philadelphia.

Coggins, C. (1972). Archaeology and the art market. Science 175: 263-266.

Coggins, C. (1975). Painting and Drawing Styles at Tikal: An Historical and Iconographic Reconstruction, Ph.D. dissertation, Department of Fine Arts, Harvard University, Cambridge, MA.

Cohodas, M. (1989). Transformations: Relationships between image and text in the ceramic paintings of the metropolitan master. In Hanks, W. F., and Rice, D. S. (eds.), Word and Image in Maya Culture: Explorations in Language, Writing and Representation, University of Utah Press, Salt Lake City, pp. 198-231.

Culbert, T. P., and Rice, D. S. (eds.) (1990). Precolumbian Population History in the Maya Lowlands, University of New Mexico Press, Albuquerque. 
Culbert, T. P., Kosakowsky, L., Fry, R. E., and Haviland, W. A. (1990). The population of Tikal, Guatemala. In Culbert, T. P., and Rice, D. S. (eds.), Precolumbian Population History in the Maya Lowlands, University of New Mexico Press, Albuquerque, pp. 103-121.

Dahlin, B. (1984). A colossus in Guatemala: The Preclassic Maya city of El Mirador. Archaeology 37: 18-25.

Demarest, A. (1984). La cerámica preclásica de El Mirador: Resultados preliminares y análisis en curso. Mesoamérica 7: 53-92.

Demarest, A. (1992). The Petexbatun Regional Archaeological Project, Final Report to NEH, Washington, DC.

Demarest, A., and Fowler, W. R. (eds.) (1984). Proyecto El Mirador de la Harvard University, 1982-1983. Mesoamérica 5: 1-160.

Dirks, N. B. (1993). The Hollow Crown, 2nd ed., University of Michigan Press, Ann Arbor.

Dockall, J. E., and Shafer, H. J. (1993). Testing the producer-consumer model for Santa Rita Corozal, Belize. Latin American Antiquity 4: 158-179.

Dunham, P. (1994). Paleo point-Surprise in a box. National Geographic (April issue).

Dunning, N. P. (1992). Lords of the Hills: Ancient Maya Settlement in the Puuc Region, Yucatán, Mexico, Prehistory Press, Madison, WI.

Dunning, N. P., and Kowalski, J. K. (1994). Lords of the hills: Classic Maya settlement pattern and political iconography in the Puuc region, Mexico. Ancient Mesoamerica 5: 63-95.

Edmonson, M. (1971). The Book of Counsel: The Popol Vuh of the Quiche Maya of Guatemala Middle American Research Institute Publication 35, Tulane University, New Orleans, LA

Fash, W. L. (1982). A Middle Formative cemetery from Copán, Honduras. Paper delivered at the annual meeting of the American Anthropological Association, Washington, DC.

Fash, W. L. (1991). Scribes, Wariors, and Kings: The City of Copan and the Ancient Maya, Thames and Hudson, London.

Fash, W. L., and Sharer, R. J. (1991). Sociopolitical developments and methodological issues at Copan, Honduras: A conjunctive perspective. Latin American Antiquity 2: 166-187.

Fauvet-Berthelot, M. F. (1986). Ethnoprehistoire de la Maison Maya, Centre d'Etudes Mexicaines et Centramericaines, Mexico.

Fialko C., Vilma (1987). Tikal, Mundo Perdido: Identificación de un complejo con implicación astronómica. Memorias del Primer Coloquio Internacional de Mayistas, UNAM, Mexico, pp. $143-164$.

Flannery, K. V., and Marcus, J. (eds.) (1983). The Cloud People: Divergent Evolution of the Zapotec and Mixtec Civilizations, Academic Press, New York.

Flannery, K. V., and Marcus, J. (1994). Early Formative Pottery of the Valley of Oaxaca, Museum of Anthropology Memoir 27, University of Michigan, Ann Arbor.

Folan, W. J. (1985). Proyecto Calakmul: Su centro urbano, estado y región en relación al concepto del resto de la gran Mesoamérica. Información No. 9, Universidad Autónoma del Sudeste, Campeche, México, pp. 161-185.

Folan, W. J., Marcus, J., Pincemin, S., Domínguez Carrasco, M., Fletcher, L., and Morales A. (1994). Calakmul: New data from an ancient Maya capital in Campeche, Mexico. Latin American Antiquity (in press).

Fortes, M., and Evans-Pritchard, E. (eds.) (1940). African Political Systems, Oxford University Press, London.

Fowler, W. R. (1984). Late Preclassic mortuary patterns and evidence for human sacrifice at Chalchuapa, El Salvador. American Anitquity 49: 603-618.

Fowler, W. R. (1989). The Cultural Evolution of Ancient Nahua Civilizations: The Pipil-Nicarao of Central America, University of Oklahoma Press, Norman.

Freidel, D. A., and Sabloff, J. A. (1984). Cozumel: Late Postclassic Settlement Patterns, Academic Press, Orlando.

Freidel, D. A., et al. (1992). Selz Foundation Yaxuna Project: Final Report of the 1991 Field Season.

Freidel, D. A., et al. (1993). Selz Foundation Yaxuna Project: Final Report of the 1992 Field Season.

Gerhardt, J. C. (1988). Preclassic Maya Architecture at Cuello, Belize, British Archaeological Reports International Series 464, Oxford, England. 
Gibson, E. (1989). The organization of Late Preclassic Maya lithic economy in the eastern Lowlands. In McAnany, P. A., and Isaac, B. L. (eds.), Research in Economic Anthropology, Supplement 4: Prehistoric Maya Economies of Belize, JAI Press, Greenwich, pp. 115-138.

Gonlin, N. (1993). Rural Household Archaeology at Copan, Honduras, Ph.D. dissertation, Dept. of Anthropology, Pennsylvania State University, University Park.

Graham, E., Jones, G. D., and Kautz, R. R. (1985). Archaeology and ethnohistory on a Spanish Colonial frontier: The Macal-Tipu project in western Belize. In Chase, A. F., and Rice, P. (eds.), The Lowland Maya Postclassic, University of Texas Press, Austin, pp. 206-214.

Graham, E., Pendergast, D., and Jones, G. D. (1989). On the fringes of conquest: Maya-Spanish contact in Colonial Belize. Science 246: 1254-1259.

Gruhn, R., and Bryan, A. (1977). Los Tapiales: A Paleoindian campsite in the Guatemala highlands. Proceedings of the American Philosophical Society 121: pp. 235-273.

Hammond, N. (ed.) (1985). Nohmul: a Prehistoric Maya Community in Belize. Excavations 1973-1983, British Archaeological Reports International Series 250, Oxford, England.

Hammond, N. (ed.) (1991). Cuello: An Early Maya Community in Belize, Cambridge University Press, Cambridge, England.

Hansen, R. (1989). Archaeological Investigations at Nakbe, Peter, Guatemala: the 1989 Season, Institute of Archaeology, University of California, Los Angeles.

Hansen, R. (1990). Excavations in the Tigre Complex, El Mirador, Peten, Guatemala, New World Archaeological Foundation Papers, No. 62, Provo, UT.

Hansen, R. (1991). The road to Nakbe. Natural History 5: 8-14.

Harrison, P. (1970). The Central Acropolis, Tikal, Guatemala, Ph.D. dissertation, Department of Anthropology, University of Pennsylvania, Philadelphia.

Harrison, P. (1979). The Lobil Postclassic phase in the southern interior of the Yucatan Peninsula. In Hammond, N., and Willey, G. R. (eds.), Maya Archaeology and Ethnohistory, University of Texas Press, Austin, pp. 189-207.

Haviland, W. A. (1985). Population and social dynamics: The dynasties and social structure of Tikal. Expedition 27: 34-41.

Haviland, W. A. (1991). Star wars at Tikal or did Caracol do what the glyphs say they did? Paper delivered at the 90th annual meeting of the American Anthropological Association, Chicago.

Henderson, J. S. (1987). Frontier at the Crossroads. In Robinson, E. J. (ed.), Interaction on the Southeast Mesoamerican Frontier, British Archaeological Reports International Serics 327 , Oxford, pp. $455-462$.

Henderson, J. S. (1992a). Elites and ethnicity along the southeastern fringe of Mesoamerica. In Chase, D. Z., and Chase, A. F. (eds.), Mesoamerican Elites, University of Oklahoma Press, Norman, pp. 157-168.

Henderson, J. S. (1992b). Variations on a theme: A frontier view of Maya civilization. In Danien, E. C., and Sharer, R. J. (eds.), New Theories on the Ancient Maya, University Museum, University of Pennsylvania, Philadelphia, pp. 161-171.

Hester, T. R. (1993). The Preceramic Settlement at Colha, Belize, proposal submitted to National Science Foundation.

Hester, T. R., and Shafer, H. J. (1984). Exploitation of chert resources by the ancient Maya of northern Belize, Central America. World Archaeology 16: 157-173.

Hester, T. R., Kelly, T., and Ligabue, G. (1981). A fluted Paleo-Indian projectile point from Belize, Central America. Colha Project Working Paper 1, Center for Archaeological Research, University of Texas, San Antonio.

Hester, T. R., Shafer, H. J., and Berry, T. (1991). Technological and comparative analyses of the chipped stone artifacts from El Pozito, Belize. In Hester, T. R., and Shafer, H. J. (eds.), Maya Stone Tools: Selected Papers from the Second Maya Lithic Conference, Prehistory Press, Madison, WI, pp. 67-83.

Hester, T. R., Iceland, H., Hudler, D., Brewington, R., Shafer, H. J., and Lohse, J. (1993). New evidence on the Preceramic era in northern Belize: A preliminary overview. In The Newsletter of the Friends of Texas Archeological Research Laboratory, University of Texas at Austin 1(2): 19-23. 
Hill, R. M. (1982). Ancient Maya houses at Cauinal and Pueblo Viejo Chixoy, El Quiche, Guatemala. Expedition 24: 40-48.

Hill, R. M., and Monaghan, J. (1987). Continuities in Highland Maya Social Organization: Ethnohistory in Sacapulas, Guatemala, University of Pennsylvania Press, Philadelphia.

Houston, S. (1987). Appendix II: Notes on Caracol epigraphy and its significance. In Chase, A. F., and Chase, D. Z. (eds.), Investigations at the Classic Maya City of Caracol, Belize: 1985-1987, Pre-Columbian Art Research Institute, Monograph 3, San Francisco, pp. 85-100.

Houston, S. (1993). Hieroglyphs and History at Dos Pilas, University of Texas Press, Austin.

Johnson, G. A. (1972). A test of the utility of central place theory in archaeology. In Ucko, P., Tringham, R., and Dimbleby, G. (eds.), Man, Settlement and Urbanism, Duckworth, London, pp. 769-785.

Johnson, G. A. (1975). Locational analysis and the investigation of Uruk local exchange systems. In Sabloff, J., and Lamberg-Karlovsky, C. (eds.), Ancient Civilization and Trade, University of New Mexico Press, Albuquerque, pp. 285-339.

Jones, G. D., Rice, D., and Rice, P. (1981). The location of Tayasal: A reconsideration in light of Petén Maya ethnohistory and archaeology. American Antiquity 46: 530-547.

Jones, J. G. (1991). Pollen Evidence of Prehistoric Forest Modification and Maya Cultivation in Belize, Ph.D. dissertation, Department of Anthropology, Texas A\&M University, College Station.

Joyce, R. (1986). Terminal Classic interaction on the southeastern Maya periphery. American Antiquity 51: 313-329.

Joyce, R. (1991). Cerro Palenque: Power and Identity on the Maya Periphery, University of Texas Press, Austin.

Kelly, T. C. (1993). Preceramic projectile-point typology in Belize. Ancient Mesoamerica 4: 205-227.

Killion, T., Sabloff, J., Tourtellot, G., and Dunning, N. (1989). Intensive surface collection of residential clusters at Terminal Classic Sayil, Yucatan. Joumal of Field Archaeology 16: 273-294.

Kirchhoff, P. (1943). Mesoamerica. Acta Americana 1: 92-107.

Krochock, R. (1988). The Hieroglyphic Inscriptions and Iconography of the Temple of the Four Lintels and Related Monuments, Chichen Itza, Yucatan, Mexico, Master's thesis, Department of Anthropology, University of Texas, Austin.

Kuper, A. (1982). Lineage theory: A critical retrospect. Annual Review of Anthropology 11: $71-95$.

Lange, F. (ed.) (1992). Wealth and Hierarchy in the Intermediate Area, Dumbarton Oaks, Washington, DC.

Laporte M., J. P., and Fialko C., V. (1990). New perspectives on old problems: Dynastic references for the Early Classic at Tikal. In Clancy, F. S., and Harrison, P. D. (eds.), $V$ ision and Revision in Maya Studies, University of New Mexico Press, Albuquerque, pp. 33-66.

Lincoln, C. E. (1986). The chronology of Chichen Itza: A review of the literature. In Sabloff, J. A., and Andrews, E. W. (eds.), Late Lowland Maya Civilization: Classic to Postclassic, University of New Mexico Press, Albuquerque, pp. 141-196.

Lounsbury, F. G. (1973). On the derivation and reading of the "Ben-Ich" prefix. In Benson, E. P. (ed.), Mesoamerican Writing Systems, Dumbarton Oaks, Washington, DC, pp. 99-143.

Lounsbury, F. G. (1989). The names of a king: Hieroglyphic variants as a key to decipherment. In Hanks, W. F., and Rice, D. S. (eds.), Word and Image in Maya Culture, University of Utah Press, Salt Lake City, pp. 73-91.

MacNeish, R. S. (1981). Second Annual Report of the Belize Archaic Archaeological Reconnaissance, Peabody Foundation for Archaeology, Phillips Academy, Andover, MA

MacNeish, R. S. (1982). Third Annual Report of the Belize Archaic Archaeological Reconnaissance, Peabody Foundation for Archaeology, Phillips Academy, Andover, MA 
MacNeish, R. S., and Nelken-Terner, A. (1983). Final Annual Report of the Belize Archaic Archaeological Reconnaissance, Boston University, Center for Archaeological Studies, Boston.

MacNeish, R. S., Wilkerson, S. J. K., and Nelken-Terner, A. (1980). First Annual Report of the Belize Archaic Archaeological Reconnaissance, Peabody Foundation for Archaeology, Phillips Academy, Andover, MA.

Marcus, J. (1973). Territorial organization of the lowland Classic Maya. Science 180: 911-916. Marcus, J. (1974). An Epigraphic Approach to the Tenitorial Organization of the Lowland Classic Maya, Ph.D. dissertation, Department of Anthropology, Harvard University, Cambridge.

Marcus, J. (1976). Emblem and State in the Classic Maya Lowlands: An Epigraphic Approach to Territorial Organization, Dumbarton Oaks, Washington, DC.

Marcus, J. (1983). Lowland Maya archaeology at the crossroads. American Antiquity 48: 454-488.

Marcus, J. (1984). Reply to Hammond and Andrews. American Antiquity 49: 829-833.

Marcus, J. (1987). The Inscriptions of Calakmul: Royal Marriage at a Maya City in Campeche, Mexico, Museum of Anthropology, Technical Report No. 21, University of Michigan, Ann Arbor.

Marcus, J. (1988). The Calakmul state and its expansionist policies (manuscript).

Marcus, J. (1989). Ancient Maya political organization. Talk delivered at Dumbarton Oaks symposium organized by Sabloff, J. A., and Henderson, J. S., Washington, DC.

Marcus, J. (1992a). Mesoamerican Writing Systems: Propaganda, Myth, and History in Four Ancient Civilizations, Princeton University Press, Princeton, NJ.

Marcus, J. (1992b). Dynamic cycles of Mesoamerican states. National Geographic Research \& Exploration 8: 392-411.

Marcus, J. (1993). Ancient Maya political organization. In Sabloff, J. A, and Henderson, J. S. (eds.), Lowland Maya Civilization in the Eighth Century A. D., Dumbarton Oaks, Washington, DC, pp. 111-183.

Marcus, J. (n.d.) From Cycle 8 to Cycle 9: The rulers of Calakmul (manuscript).

Marcus, J., and Flannery, K. (1994). Ancient Zapotec ritual and religion: An application of the direct historical approach. In Renfrew, $\mathrm{C}$., and Zubrow, E. (eds.), The Ancient Mind, Cambridge University Press, Cambridge, pp. 55-74.

Marcus, J., and Folan, W. J. (1994a). Una estela más del siglo V y nueva información sobre Pata de Jaguar, gobernante de Calakmul en el siglo VII. Gaceta Universitaria, No. 15-16, Universidad Autónoma de Campeche, Mexico.

Marcus, J., and Folan, W. J. (1994b). Una estela más del siglo V. Crónica (Campeche newspaper, July 17), pp. 1-3.

Matheny, R. T. (ed.) (1980). El Mirador, Peten, Guatemala, New World Archaeological Foundation Paper 45, Brigham Young University, Provo, UT.

Matheny, R. T. (1986). Investigations at El Mirador, Peten, Guatemala. National Geographic Research 2: 332-353.

Mathews, P. (1985). Maya Early Classic monuments and inscriptions. In Willey, G. R., and Mathews, P. (eds.), A Consideration of the Early Classic Period in the Maya Lowlands, Institute for Mesoamerican Studies, No. 10, State University of New York at Albany, pp. $5-54$.

McAnany, P. A. (1989a). Introduction. In McAnany, P. A., and Isaac, B. L. (eds.), Research in Economic Anthropology Supplement 4, Prehistoric Maya Economies of Belize, JAI Press, Greenwich, CT, pp. 1-13.

McAnany, P. A (1989b). Economic foundations of prehistoric Maya society: Paradigms and concepts. In McAnany, P. A., and Isaac, B. L. (eds.), Research In Economic Anthropology Supplement 4, Prehistoric Maya Economies of Belize, JAI Press, Greenwich, CT, pp. 347-372.

McAnany, P. A. (1989c). Stone-tool production and exchange in the eastern Maya lowlands: The consumer perspective from Pulltrouser Swamp, Belize. American Antiquity 54: 332-346.

McAnany, P. A. (1991). K'axob, National Science Foundation proposal (manuscript). 
McAnany, P. A. (1992). Ancestor veneration at K'axob, Belize: Excavations and analysis, 1992 Context (Boston University Center for Archaeological Studies), Vol. 10, nos. 3-4, pp. 1-5.

McSwain, R. (1991). A comparative evaluation of the producer-consumer model for lithic exchange in northern Belize, Central America. Latin American Antiquity 2: 337-351.

Miller, A. G. (1982). On the Edge of the Sea: Mural Painting at Tancah-Tulum, Dumbarton Oaks, Washingtơn, DC

Miller, A. G. (1985). The Postclassic sequence of Tancah and Tulum, Quintana Roo, Mexico. In Chase, A. F., and Rice, P. M. (eds.), The Lowland Maya Postclassic, University of Texas Press, Austin, pp. 31-49.

Morley, S. G. (1946). The Ancient Maya, Stanford University Press, Stanford.

Morley, S. G., Brainerd, G. W., and Sharer, R. J. (1983). The Ancient Maya, 4th ed., Stanford University Press, Stanford, CA.

Neivens, M. (1976). El Pozito, A Late Classic site. In Buhler, R. (ed.), Recent Archaeology in Belize, Occasional Publications 3, Belize Institute for Social Research, pp. 53-63.

Nicholson, H. B. (1957). Topiltzin Quetzalcoatl of Tollan: A Problem in Mesoamerican Ethnohistory, Ph.D. dissertation, Department of Anthropology, Harvard University, Cambridge.

Parker, A. C. (1922). Archaeological History of New York, New York State Museum Bulletin, Albany, pp. 235-238.

Pendergast, D. M. (1981). Lamanai, Belize: Summary of excavation results, 1974-1980. Joumal of Field Archaeology 8: 29-53.

Pendergast, D. M. (1985). Lamanai, Belize: An updated view. In Chase, A. F., and Rice, P. M. (eds.), The Lowland Maya Postclassic, University of Texas Press, Austin, pp. 91-103.

Pendergast, D. M. (1986). Stability through change: Lamanai, Belize, from the ninth to the seventeenth century. In Sabloff, J. A, and Andrews, E. W. (eds.), Late Lowland Maya Civilization: Classic to Postclassic, University of New Mexico Press, Albuquerque, pp. 223-249.

Pincemin, S. (1989). La cerámica de Calakmul. Paper given at the Primer Congreso Internacional de Mayistas, August 14-19, 1989, San Cristóbal de Las Casas, Mexico.

Pohl, M., Pope, K., Jones, J., Jacob, J., and Lentz, D. (1994). Maize agriculture and social competition in the eastern Maya lowlands (manuscript).

Pollock, H., Roys, R., Proskouriakoff, T., and Smith, A. L. (1962). Mayapan, Yucatan, Mexico, Carnegie Institution of Washington Publication 619, Washington, DC.

Postgate, J. N. (1992). Early Mesopotamia, Routledge, New York.

Potter, D. (1991a). Colha and The Origins of Maya Civilization, Ph.D. dissertation, Department of Anthropology, Harvard University, Cambridge, MA

Potter, D. (1991b). A descriptive taxonomy of Middle Preclassic chert tools at Colha, Belize In Hester, T. R., and Shafer, H. J. (eds.), Maya Stone Tools: Selected Papers from the Second Maya Lithic Conference, Prehistory Press, Madison, WI, pp. 21-29.

Potter, D. (1993). Analytical approaches to Late Classic Maya lithic industries. In Sabloff, J. A. and Henderson, J. S. (eds.), Lowland Maya Civilization in the Eighth Century A.D., Dumbarton Oaks, Washington, DC, pp. 273-298.

Proskouriakoff, T. (1963). Historical data in the inscriptions of Yaxchilan, Part I. Estudios de Cultura Maya 3: 149-167.

Proskouriakoff, T. (1964). Historical data in the inscriptions of Yaxchilan, Part II. Estudios de Cultura Maya 4: 177-201.

Proskouriakoff, T. (1993). Joyce, R. (ed.), Maya History, University of Texas Press, Austin.

Pyburn, K. A. (1987). Settlement patterns at Nohmul: A prehistoric Maya city in northern Belize. Mexicon 9: 110-114.

Pyburn, K. A. (1989). Nohmul, British Archaeological Reports International Series 509, Oxford, England.

Pyburn, K A. (1990). Settlement patterns at Nohmul: Preliminary results of four excavation seasons. In Culbert, T. P., and Rice, D. S. (eds.), Precolumbian Population History in the Maya Lowlands, University of New Mexico Press, Albuquerque, pp. 183-197.

Recinos, A. (1950). Popol Vuh, English translation by Goetz, D., and Morley, S. G., University of Oklahoma Press, Norman. 
Reents-Budet, D. (1994). Comment cited in Ingalls, Z., "Scholars debate how to approach objects known to have been looted." The Chronicle of Higher Education March 9, p. A15.

Renfrew, C., and Cherry, J. F. (1986). Preface. In Renfrew, C., and Cherry, J. F. (eds.), Peer Polity Interaction and Socio-Political Change, Cambridge University Press, Cambridge, pp. vii-viii.

Rice, D. (1986). The Peten Postclassic: A settlement perspective. In Sabloff, J. A, and Andrews, E. W. (eds.), Late Lowland Maya Civilization: Classic to Postclassic, University of New Mexico Press, Albuquerque, pp. 301-344.

Rice, D., and Rice, P. (1981). Muralla de Leon: A lowland Maya fortification. Journal of Field Archaeology 8: 271-288.

Rice, P. (1986). The Peten Postclassic: Perspectives from the central Peten lakes. In Sabloff, J. A., and Andrews, E. W. (eds.), Late Lowland Maya Civilization: Classic to Postclassic, University of New Mexico Press, Albuquerque, pp. 251-299.

Rice, P. (1987). Macanche Island, El Peten, Guatemala: Excavations, Pottery, and Artifacts, University of Florida Press, Gainesville.

Rice, P., and Rice, D. (1985). Topoxte, Macanche, and the central Peten Postclassic. In Chase, A. F., and Rice, P. M. (eds.), The Lowland Maya Postclassic, University of Texas Press, Austin, pp. 166-183.

Ricketson, O., and Ricketson, E. (1937). Uaxactun, Guatemala: Group E, 1926-1931, Carnegie Institution of Washington, Publication 477, Washington, DC.

Ringle, W., and Andrews, E. W., V (1988). Formative residences at Komchen, Yucatan, Mexico. In Wilk, R. R., and Ashmore, W. (eds.), House and Household in the Mesoamerican Past, University of New Mexico Press, Albuquerque, pp. 171-197.

Ringle, W., and Andrews, E. W., V (1990). The demography of Komchen, An early Maya Town in northern Yucatan. In Culbert, T. P., and Rice, D. S. (eds.), Precolumbian Population History in the Maya Lowlands, University of New Mexico Press, Albuquerque, pp. 215-243.

Ringle, W., Bey, G., and Péraza, C. (1991). An Itzá empire in northern Yucatán? Paper presented at the 47th International Congress of Americanists, New Orleans, LA.

Rivera Dorado, M. (1992). Oxkintok 4, Misión Arqueológica de España en México, Madrid.

Robertson, R., and Freidel, D. (eds.) (1986). Archaeology at Cerros, Belize, Central America, Southern Methodist University, Dallas.

Robin, C. (1989). Preclassic Maya Burials at Cuello, Belize, British Archaeological Reports International Series 489, Oxford, England.

Robin, C., and Hammond, N. (1991). Burial practices. In Hammond, N. (ed.), Cuello, Cambridge University Press, Cambridge, pp. 204-225.

Robles C., F., and Andrews, A. P. (1986). A review and synthesis of recent Postclassic archaeology in northern Yucatan. In Sabloff, J. A., and Andrews, E. W. (eds.), Late Lowland Maya Civilization: Classic to Postclassic, University of New Mexico Press, Albuquerque, pp. 53-98.

Sabloff, J. A (1975). Excavations at Seibal: Ceramics, Memoirs of the Peabody Museum, Harvard University, Vol. 13, No. 2, Cambridge.

Sabloff, J. A. (1983). Classic Maya settlement pattern studies: Past problems, future prospects. In Vogt, E., and Leventhal, R. (eds.), Prehistoric Settlement Pattern Studies: Retrospect and Prospect, University of New Mexico Press, Albuquerque, pp. 413-422.

Sabloff, J. A. (1989). The Cities of Ancient Mexico, Thames and Hudson, New York.

Sabloff, J. A. (1990). The New Archaeology and the Ancient Maya, W. H. Freeman, Scientific American Library, New York.

Sabloff, J. A. (1992). Interpreting the collapse of Classic Maya civilization: A study of changing archaeological perspectives. In Embree, L. (ed.), Meta-Archaeology, Boston Studies in the Philosophy of Science, Vol. 147, Kluwer Academic Publishers, Boston, pp. 99-120.

Sabloff, J. A, and Andrews, E. W., V (eds.) (1986). Late Lowland Maya Civilization, University of New Mexico Press, Albuquerque.

Sabloff, J. A., and Henderson, J. S. (eds.) (1993). Lowland Maya Civilization in the Eighth Century $A$. D., Dumbarton Oaks, Washington, DC. 
Sabloff, J. A., and Tourtellot, G. (1991). The Ancient Maya City of Sayil: The Mapping of a Puuc Region Center, Middle American Research Institute Publication 60, Tulane University, New Orleans, LA.

Sabloff, J. A, and Tourtellot, G. (1992). Beyond temples and palaces: Recent settlement pattern research at the ancient Maya city of Sayil (1983-1985). In Danien, E. C., and Sharer, R. J. (eds.), New Theories on the Ancient Maya, University Museum, University of Pennsylvania, Philadelphia, pp. 155-160.

Sabloff, J. A., and Willey, G. R. (1967). The collapse of Maya civilization in the southern lowlands: A consideration of history and process. Southwestern Joumal of Anthropology 23: 311-336.

Sanders, W. T. (1974). Chiefdom to state: Political evolution at Kaminaljuyú, Guatemala. In Moore, C. B. (ed.), Reconstructing Complex Societies: An Archaeological Colloquium, Supplement to the Bulletin of the American Schools of Oriental Research, No. 20, Boston, pp. 97-116.

Schele, L., and Freidel, D. A. (1990). A Forest of Kings, William Morrow, New York.

Schortman, E. M. (1986). Interaction between the Maya and non-Maya along the Late Classic southeast Maya periphery: The view from the lower Motagua Valley, Guatemala. In Urban, P. A., and Schortman, E. M. (eds.), The Southeast Maya Periphery, University of Texas Press, Austin, pp. 114-137.

Schortman, E. M. (1989). Interregional interaction in prehistory: The need for a new perspective. American Antiquity 54: 52-65.

Schortman, E. M., and Nakamura, S. (1992). A crisis of identity: Late Classic competition and interaction on the southeast Maya periphery. Latin American Antiquity 2: 311-336.

Shafer, H. J. (1991). Late Preclassic formal tool production at Colha, Belize. In Hester, T. R., and Shafer, H. J. (eds.), Maya Stone Tools: Selected Papers from the Second Maya Lithic Conference, Prehistory Press, Madison, WI, pp. 31-44.

Shafer, H. J., and Hester, T. R. (1983). Ancient Maya chert workshops in northern Belize, Central America. American Antiquity 48: 519-543.

Sharer, R. J. (1982). Did the Maya collapse? A New World perspective on the demise of Harappan civilization. In Possehl, G. (ed.), Harappan Civilization, New Delhi, pp. 367-383.

Sharer, R. J. (1991). Diversity and continuity in Maya civilization: Quirigua as a case study. In Culbert, T. P. (ed.), Classic Maya Political History, Cambridge University Press, Cambridge, pp. 180-198.

Sharer, R. J. (1992). The Preclassic origin of lowland Maya states. In Danien, E. C., and Sharer, R. J. (eds.), New Theories on the Ancient Maya, University Museum, University of Pennsylvania, Philadelphia, pp. 131-136.

Sharer, R. J. (1993a). The social organization of the Late Classic Maya: Problems of definition and approaches. In Sabloff, J. A, and Henderson, J. S. (eds.), Lowland Maya Civilization in the Eighth Century A. D., Dumbarton Oaks, Washington, D. C., pp. 91-109.

Sharer, R. J. (1993b). The First Ruler of Copán and "Margarita" Platform, proposal submitted to National Geographic Society, Washington, DC,

Sharer, R. J., and Sedat, D. W. (1987). Archaeological Investigations in the Northern Maya Highlands, Guatemala: Interaction and the Development of Maya Civilization, University Museum Monograph 59, University of Pennsylvania, Philadelphia.

Sharer, R. J., Miller, J. C., and Traxler, L. P. (1992). Evolution of Classic period architecture in the Eastern Acropolis, Copan: A progress report. Ancient Mesoamerica 3: 145-159.

Sharer, R. J., Sedat, D., Miller, J., Morales, A., Traxler, L., Carrelli, C., Centeno, L., and López, F. (1994). Programa de investigación de la Acrópolis temprana de la Universidad de Pennsylvania: Informe de la temporada de 1993, Instituto Hondureño de Antropología e Historia, Copán Ruinas.

Sheets, P. (1992). The Cerén Site, Harcourt, Brace, Jovanovich, New York.

Sheets, P. (1993). Introduction to the 1993 research season, Cerén, El Salvador. In Sheets, P., and Simmons, S. (eds.), Preliminary Report of the Cerén Research Project, 1993 Season, University of Colorado, Boulder.

Smith, A. L. (1950). Uaxactun, Guatemala: Excavations of 1931-1937, Carnegie Institution Publication 588, Washington, DC. 
Smith, A. L. (1982). Excavations at Seibal: Major Architecture and Caches, Memoirs of the Peabody Museum, Harvard University, Vol. 15, No. 1, Cambridge.

Southall, A. (1956). Alur Society, Heffer Press, Cambridge.

Southall, A. (1988). The segmentary state in Africa and Asia. Comparative Studies in Society and History 30: 52-82.

Southall, A. (1991). The segmentary state: From the imaginary to the material means of production. In Claessen, H., and van de Velde, P. (eds.), Early State Economics, Transaction Publishers, New Brunswick, NJ, pp. 75-96.

Spencer, C. S. (1990). On the tempo and mode of state formation: neoevolutionism reconsidered. Journal of Anthropological Archaeology 9: 1-30.

Strong, W. D. (1933). The Plains culture area in the light of archaeology. American Anthropologist 35: 271-287.

Strong, W. D. (1935). An Introduction to Nebraska Archaeology, Smithsonian Miscellaneous Collections, Vol. 93, No. 10. Washington, DC.

Strong, W. D. (1947). Review of S. G. Morley's The Ancient Maya. American Anthropologist 49: $640-645$.

Swadesh, M. (1967). Lexicostatistic classification. In McQuown, N. (ed.), Handbook of Middle American Indians, Vol. 5, University of Texas Press, Austin, pp. 79-115.

Taylor, W. W. (1948). A Study of Archeology, Memoir Series of the American Anthropologist Association, No. 69, Menasha, WI.

Tobler, W., and Wineberg, S. (1971). A Cappadocian speculation. Nature 231 (5297): 39-41.

Tourtellot, G., and Sabloff, J. A. (1989). Approaches to household and community structure at Sayil, Yucatan. In MacEachern, S., Archer, D., and Galvin, R. (eds.), Households and Communities, Archaeological Association of the University of Calgary, pp. 363-370.

Tourtellot, G., III, Clarke, A., and Hammond, N. (1993). Mapping La Milpa: A Maya city in northwestern Belize. Antiquity 67: 96-108.

Turner, B. L., and Harrison, P. D. (eds.) (1983). Pulltrouser Swamp, University of Texas Press, Austin.

Trigger, B. G. (1993). Early Civilizations, American University in Cairo Press, Cairo, Egypt.

Valdez, F. (1987). The Archaeological Ceramics of Colha, Belize, Ph.D. dissertation, Department of Anthropology, Harvard University, Cambridge.

Vogt, E. Z. (1964a). The genetic model and Maya cultural development. In Vogt, E. Z., and Ruz L., A. (eds.), Desarrollo Cultural de los Mayas, UNAM, Mexico, pp. 9-48.

Vogt, E. Z. (1964b). Ancient Maya and contemporary Tzotzil cosmology: A comment on some methodological problems. American Antiquity 30: 192-195.

Vogt, E. Z., and Ruz Lhuillier, A. (eds.) (1964). Desarrollo Cultural de los Mayas, UNAM, Mexico.

Webster, D. (1976). Defensive Earthworks at Becan, Campeche, Mexico, Middle American Research Institute Publication 41, Tulane University, New Orleans.

Webster, D. (1977). Warfare and the evolution of Maya civilization. In Adams, R. E. W. (ed.), The Origins of Maya Civilization, University of New Mexico Press, Albuquerque, pp. 335-371.

Webster, D. (1993). The study of Maya warfare: What it tells us about the Maya and what it tells us about Maya archaeology. In Sabloff, J. A, and Henderson, J. S. (eds.), Lowland Maya Civilization in the Eighth Century A.D., Dumbarton Oaks, Washington, DC., pp. $415-444$.

Webster, D., and Freter, A. (1990a). The demography of Late Classic Copan. In Culbert, T. P., and Rice, D. S. (eds.), Precolumbian Population History in the Maya Lowlands, University of New Mexico Press, Albuquerque, pp. 37-61.

Webster, D., and Freter, A. (1990b). Settlement history and the Classic collapse at Copan: A refined chronological perspective. Latin American Antiquity 1: 66-85.

Webster, D., and Gonlin, N. (1988). Household remains of the humblest Maya. Joumal of Field Archaeology 15: 169-190.

Webster, D., Sanders, W. T., and van Rossum, P. (1992). A simulation of Copan population history and its implications. Ancient Mesoamerica 3: 185-198. 
Webster, D., Freter, A, and Rue, D. (1993). The obsidian hydration dating project at Copan: A regional approach and why it works. Latin American Antiquity 4: 303-324.

Wedel, W. (1938). The direct-historical approach in Pawnee archaeology. Smithsonian Miscellaneous Collections, Vol. 97, No. 7, Washington, DC.

Wilk, R., and Ashmore, W. (eds.) (1988). Household and Community in the Mesoamerican Past, University of New Mexico Press, Albuquerque.

Willey, G. R. (ed.) (1978). Excavations at Seibal, Peabody Museum of Archaeology and Ethnology, Memoir 14, Harvard University, Cambridge.

Wright, A. C. S., Romney, D. H., Arbuckle, R. H., and Vial, V. E. (1959). Land in British Honduras, Colonial Research Publication 24, Her Majesty's Stationery Office, London.

Wright, H. T. (1977). Recent research on the origins of the state. Annual Review of Anthropology 6: 379-397.

Wright, H. T., and Johnson, G. A. (1975). Population, exchange, and early state formation in southwestern Iran. American Anthropologist 77: 267-289.

Yoffee, N. (1993). Comments on segmentary states. Paper given at Arizona State University, Tempe.

Zeitlin, R. N. (1984). A summary report on three seasons of field investigations into the Archaic period prehistory of lowland Belize. American Anthropologist 86: 358-369.

\section{BIBLIOGRAPHY OF RECENT LITERATURE}

Abrams, E. M. (1987). Economic specialization and constnuction personnel in Classic period Copan, Honduras. American Antiquity 52: 485-499.

Abrams, E. M., and Rue, D. (1989). The causes and consequences of deforestation among the prehistoric Maya. Human Ecology 16: 377-395.

Adams, R. E. W. (1980). Swamps, canals, and the locations of ancient Maya cities. Antiquity 54: 206-214.

Adams, R. E. W. (ed.) (1987). Río Azul Reports: Number 3, The 1985 Season. Proyecto Rio Azul Informe Tres: 1985, University of Texas-San Antonio, San Antonio.

Adams, R. E. W. (ed.) (1989). Rio Azul Reports: Number 4, The 1986 Season. Proyecto Rio Azul Informe Cuatro: 1986, University of Texas-San Antonio, San Antonio.

Adams, R. E. W. (1991). Nucleation of population and water storage among the ancient Maya. Science 251: 632 .

Adams, R. E. W., and Robichaux, H. R. (1992). The Early Classic painted tombs of Río Azul. National Geographic Research \& Exploration 8: 412-427.

Alcorn, J. (1984). Huastec Mayan Ethnobotany, University of Texas Press, Austin.

Aldenderfer, M. S., Kimball, L. R., and Sievert, A (1989). Microwear analysis in the Maya lowlands: The use of functional data in a complex-society setting. Journal of Field Archaeology 16: 47-60.

Andrews, A. P. (1983). Maya Salt Production and Trade, University of Arizona Press, Tucson. Andrews, E. W., V (1986). Olmec jades from Chacsinkin, Yucatan, and Maya ceramics from La Venta, Tabasco. In Andrews, E. W., V (ed.), Research and Reflections in Archaeology and History: Essays in Honor of Doris Stone, Middle American Research Institute Publication 57, Tulane University, New Orleans, LA, pp. 11-49.

Andrews, E. W., V (1987). A cache of early jades from Chacsinkin, Yucatan. Mexicon 9(4): $78-85$.

Andrews, E. W., V (1990). Early ceramic history of the lowland Maya. In Clancy, F. S., and Harrison, P. D. (eds.), Vision and Revision in Maya Studies, University of New Mexico Press, Albuquerque, pp. 1-19.

Andrews, E. W., V, and Fash, B. W. (1992). Continuity and change in a royal Maya residential complex at Copán. Ancient Mesoamerica 3: 63-88. 
Andrews, E. W., V, and Sabloff, J. A. (1986). Classic to Postclassic: A summary discussion. In Sabloff, J. A, and Andrews, E. W. (eds.), Late Lowland Maya Civilization: Classic to Postclassic, University of New Mexico Press, Albuquerque, pp. 433-456.

Ashmore, W. (1980). Discovering Early Classic Quirigua. Expedition 23: 35-44.

Ashmore, W. (1981). Some issues of method and theory in lowland Maya settlement archaeology. In Ashmore, W. (ed.), Lowland Maya Settlement Patterns, University of New Mexico Press, Albuquerque, pp. 37-69.

Ashmore, W. (1986). Peten cosmology in the Maya southeast: An analysis of architecture and settlement patterns at Classic Quirigua. In Urban, P. A, and Schortman, E. M. (eds.), The Southeast Maya Periphery, University of Texas Press, Austin, pp. 35-49.

Ashmore, W. (1987). Cobble crossroads: Gualjoquito architecture and external elite ties. In Robinson, E. J. (ed.), Prehistoric Interaction on the Southeast Mesoamerican Periphery: Honduras and El Salvador, British Archaeological Reports International Series 327, Oxford, England, pp. 28-48.

Ashmore, W. (1989). Construction and cosmology: Politics and ideology in lowland Maya settlement patterns. In Hanks, W. F., and Rice, D. S. (eds.), Word and Image in Maya Culture, University of Utah Press, Salt Lake City, pp. 272-286.

Ashmore, W. (1991). Site-planning principles and concepts of directionality among the ancient Maya. Latin American Antiquily 2: 199-226.

Ashmore, W. (1992). Deciphering Maya architectural plans. In Danien, E. C., and Sharer, R. J. (eds.), New Theories on the Ancient Maya, University Museum, University of Pennsylvania, Philadelphia, pp. 173-184.

Ashmore, W., Schortman, E. M., Urban, P. A., Benyo, J. C., Weeks, J. M., and Smith, S. (1987). Ancient society in Santa Bárbara, Honduras, National Geographic Research 3: 232-254.

Atran, S. (1993). Itza Maya tropical agro-forestry. Current Anthropology 34(5): 633-700.

Awe, J. J. (1993). A Preliminary Study of the Emengence of Cultural Complexity in the Upper Belize Valley Region, presented at the 26th Chacmool Conference, Nov. 11-14, Calgary, Alberta.

Awe, J. J., and Campbell, M. D. (eds.) (1991). Report of the Third Season (1990) of Investigations at Cahal Pech, Belize, Trent University, Peterborough, Ontario, Canada.

Awe, J. J., Bill, C., and Campbell, M. D. (eds.) (1990). The Cahal Pech, Belize Project: A Progress Report of the Second (1989) Season of Investigations, Trent University, Peterborough, Ontario, Canada.

Awe, J. J., Vinuales, J., Velasco, M., and Novela, R. (1992). Investigations at the Cas Pek Group in the western periphery of Cahal Pech, Belize. In Awe, J. J., and Campbell, M. D. (eds.), Progress Report of the Fourth Season (1991) of Investigations at Cahal Pech, Belize, Trent Univerity, Peterborough, Ontario, Canada, pp. 51-58.

Ball, J. W., and Taschek, J. T. (1989). Teothuacan's fall and the rise of the Itza: Realignments and role changes in the Terminal Classic Maya lowlands. In Diehl, R. A, and Berlo, J. C. (eds.), Mesoamerica after the Decline of Teotihuacan, A. D. 700-900, Dumbarton Oaks, Washington, D. C., pp. 187-200

Ball, J. W., and Taschek, J. T. (1991). Late Classic lowland Maya political organization and central-place analysis. Ancient Mesoamerica 2: 149-165.

Barrera R., A., Gallareta N., T., Pérez A., C., Toscano H., L., and Huchím, J. (1988). Restauración e investigación arqueológica en Uxmal (1986-1987). Mexicon 10: 37-40.

Barrera Vásquez, A. (1980). Diccionario Maya Cordemex: Maya-Español, Español-Maya, Ediciones Cordemex, Mérida, Mexico.

Becker, M. J. (1986). Household shrines at Tikal, Guatemala: Size as a reflection of economic status. Revista Española de Antropología Americana 12: 11-29.

Becker, M. J. (1992). Burials as caches, caches as burials: A new interpretation of the meaning of ritual deposits among the Classic period lowland Maya. In Danien, E. C., and Sharer, R. J. (eds.), New Theories on the Ancient Maya, University Museum, University of Pennsylvania, Philadelphia, pp. 185-196.

Beetz, C. P., and Satterthwaite, L. (1981). The Monuments and Inscriptions of Caracol, Belize, University Museum Monograph 45, University of Pennsylvania, Philadelphia. 
Benavides C., A. (1981). Los Caminos de Cobá y sus Implicaciones Sociales, INAH, Mexico. Benson, E. P. (ed.) (1989). City-States of the Maya: Art and Architecture, Rocky Mountain Institute for Pre-Columbian Studies, Denver.

Berlin, H. (1958). El glifo "emblema" en las inscripciones mayas. Joumal de la Société des Américanistes 47: 111-119.

Berlin, H. (1977). Signos y Significados en las Inscripciones Mayas, Instituto Nacional del Patrimonio Cultural de Guatemala, Guatemala.

Bishop, R. L., and Lange, F. W. (1991). Jade in Meso-America. In Keverne, R. (ed.), Jade, Anness Law, Oxford.

Black, S. L. (1990). The Carnegie Uaxactun Project and the development of Maya archaeology. Ancient Mesoamerica 1: 257-276.

Bolles, J. S. (1977). Las Monjas: A Major Pre-Mexican Architectural Complex at Chichén Itzá, University of Oklahoma Press, Norman.

Boone, E. H., and Willey, G. R. (eds.) (1988). The Southeast Classic Maya Zone, Dumbarton Oaks, Washington, DC.

Brady, J. E. (1988). The sexual connotation of caves in Mesoamerican ideology. Mexicon 10: $51-55$.

Brady, J. E., and Veni, G. (1992). Man-made and pseudo-karst caves: The implication of subsurface geologic features within Maya centers. Geoarchaeology 7(2): 149-167.

Bruhns, K. O. (1980). Cihuatan: An Early Postclassic town of El Salvador, University of Missouri Monographs in Anthropology, No. 5, Columbia.

Carmean, K. (1991). Architectural labor investment and social stratification at Sayil, Yucatán, Mexico. Latin American Antiquity 2: 151-165.

Carneiro, R. L. (1981). The chiefdom: Precursor of the state. In Jones, G. D., and Kautz, R. R. (eds.), The Transition to Statehood in the New World, Cambridge University Press, Cambridge, pp. 37-79.

Chamberlain, R. S. (1948). The Conquest and Colonization of Yucatan, 1517-1550, Carnegie Institution of Washington 582, Washington, DC.

Chase, A. F., and Chase, D. Z. (1981). Archaeological investigations at Nohmul and Santa Rita, Belize: 1979-1980. Mexicon 3: 42-44.

Chase, A. F., and Chase, D. Z. (1989). The investigation of Classic period warfare at Caracol, Belize. Mayab 5: 5-18.

Chase, A. F., and Rice, P. (eds.) (1985). The Lowland Maya Postclassic, University of Texas Press, Austin.

Chase, D. Z., and Chase, A. F. (1982). Yucatec influence in Terminal Classic northern Belize. American Antiquity 47: 596-614.

Chase, D. Z., and Chase, A. F. (1988). A Postclassic perspective: Excavations at the Maya site of Santa Rita Corozal, Belize, Pre-Columbian Art Research Institute Monograph 4, Herald Printers, Monterey, California.

Chase, D. Z., and Chase, A. F. (eds.) (1992). Mesoamerican Elites: An Archaeological Assessment, University of Oklahoma Press, Norman.

Chase, D. Z., Chase, A. F., and Haviland, W. A. (1990). The Classic Maya city: Reconsidering the Mesoamerican urban tradition. American Anthropologist 92: 499-506.

Clancy, F. S., and Harrison, P. D. (eds.) (1990). Vision and Revision in Maya Studies, University of New Mexico Press, Albuquerque.

Coe, W. R. (1965). Tikal, Guatemala, and emergent Maya civilization. Science 147: 1401-1419.

Coe, W. R. (1967). Tikal: A Handbook of the Ancient Maya Ruins, University Museum, University of Pennsylvania, Philadelphia.

Coggins, C. C., and Shane, O. C., III (eds.) (1984). Cenote of Sacrifice: Maya Treasures from the Sacred Well at Chichén Itzá, University of Texas Press, Austin.

Culbert, T. P. (1988a). The collapse of Classic Maya civilization. In Yoffee, N., and Cowgill, G. L. (eds.), The Collapse of Ancient States and Civilizations, University of Arizona Press, Tucson, pp. 69-101.

Culbert, T. P. (1988b). Political history and the decipherment of Maya glyphs. Antiquity 62: $135-152$. 
Culbert, T. P. (ed.) (1991). Classic Maya Political History, Cambridge University Press, Cambridge.

Culbert, T. P. (1993). The Ceramics of Tikal: Vessels from the Burials, Caches, and Problematical Deposits, Tikal Report 25, Part A, University Museum, University of Pennsylvania, Philadelphia.

Dahlin, B. H., and Litzinger, W. J. (1986). Old bottles, new wine: The function of chultuns in the Maya lowlands. American Antiquity 51: 721-736.

Danien, E. C., and Sharer, R. J. (eds.) (1992). New Theories on the Ancient Maya, University Museum, Philadelphia.

Demarest, A. A. (1992). Ideology in ancient Maya cultural evolution: The dynamics of galactic polities. In Demarest, A. A., and Conrad, G. W. (eds.), Ideology and Pre-Columbian Civilizations, SAR Press, Santa Fe, NM, pp. 135-157.

Demarest, A. A., and Conrad, G.W. (eds.) (1992). Ideology and Precolumbian Civilizations, SAR Press, Santa Fe, NM.

Demarest, A. A., and Foias, A. E. (1993). Mesoamerican horizons and the cultural transformations of Maya civilization. In Rice, D. S. (ed.), Latin American Horizons, Dumbarton Oaks, Washington, DC, pp. 147-191.

de Montmollin, O. (1989). The Archaeology of Political Structure: Settlement Analysis in a Classic Maya Polity, Cambridge University Press, Cambridge.

de Montmollin, O. (1992). The 1988 survey in the lower Rosario Valley, Chiapas, Mexico. In Saunders, N. (ed.), Ancient America, Oxbow Books, Oxford, pp. 39-60.

Dreiss, M. L. (1988). Obsidian at Colha, Belize: A technological and distributional study based on trace element data. Papers of the Colha Project, Vol. 4, Texas Archeological Research Laboratory, University of Texas, Austin/University of Texas at San Antonio.

Drennan, R. D. (1984). Long-distance movement of goods in prehispanic Mesoamerica: Its importance in the complex societies of the Formative and Classic. American Antiquity 49: $27-43$.

Drennan, R. D. (1988). Household location and compact versus dispersed settlement in prehispanic Mesoamerica. In Wilk, R. R., and Ashmore, W. (eds.), Household and Community in the Mesoamerican Past, University of New Mexico, Albuquerque, pp. 273-293.

Drollinger, H. D. (1989). An Investigation of a Late Preclassic Maya Chert Workshop from Colha, Belize, Master's thesis, Texas A\&M, College Station.

Fash, W. L. (1988). A new look at Maya statecraft from Copan, Honduras. Antiquity 62: 157-169.

Fedick, S. L. (1989). The economics of agricultural land use and settlement in the upper Belize Valley. In McAnany, P. A., and Isaac, B. L. (eds.), Research in Economic Anthropology, Supplement 4, Prehistoric Maya Economies of Belize, JAI Press, Greenwich, CT, pp. 215-253.

Fedick, S. L. (1994). Ancient Maya agricultural terracing in the upper Belize River area: Computer-aided modeling and the results of initial field investigations. Ancient Mesoamerica 5: 107-127.

Fedick, S. L., and Ford, A. (1990). The prehistoric agricultural landscape of the central Maya lowlands: An examination of local variability in a regional context. World Archaeology 22: $18-33$.

Folan, W. J. (n.d.) Calakmul site map and survey results (manuscript in possession of author).

Folan, W. J., Kintz, E. R., and Fletcher, L. A. (1983). Coba: A Classic Maya Metropolis, Academic Press, New York.

Ford, A. (1986). Population Growth and Social Complexity: An Examination of Settlement and Environment in the Central Maya Lowlands, Anthropological Papers, No. 35, Arizona State University, Tempe.

Ford, A., and Olson, K. (1989). Aspects of ancient Maya household economy: Variation in chipped stone production and consumption. In McAnany, P. A, and Isaac, B. L. (eds.), Research in Economic Anthropology, Supplement 4, Prehistoric Maya Economies of Belize, JAI Press, Greenwich, CT, pp. 185-211. 
Forsyth, D. (1980). Report on some ceramics from the Peten, Guatemala. In Matheny, R. T. (ed.), El Mirador, Peten, Guatemala, Papers of the New World Archaeological Foundation 45. Brigham Young University, Provo, UT, pp. 58-82.

Fox, J. W. (1980). Lowland to highland mexicanization processes in southern Mesoamerica. American Antiquity 45: 43-54.

Fox, J. W. (1987). Maya Postclassic State Formation, Cambridge University Press, Cambridge.

Fox, J. W. (1989). On the rise and fall of Tulans and Maya segmentary states. American Anthropologist 91: 656-681.

Freidel, D. A. (1981). Continuity and disjunction: Late Postclassic settlement patterns in northern Yucatan. In Ashmore, W. (ed.), Lowland Maya Settlement Patterns, University of New Mexico Press, Albuquerque, pp. 311-332.

Freidel, D. A (1986). Maya warfare: An example of peer polity interaction. In Renfrew, C., and Cherry, J. F. (eds.), Peer Polity Interaction and Socio-Political Change, Cambridge University Press, Cambridge, England, pp. 93-108.

Freidel, D. A., and Schele, L. (1988). Kingship in the Late Preclassic Maya lowlands: The instruments and places of ritual power. American Anthropologist 90: 547-567.

Fry, R. E. (1979). The economics of pottery at Tikal, Guatemala: Models of exchange for serving vessels. American Antiquity 44: 494-512.

Fry, R. E. (1989). Regional ceramic distributional patterning in northern Belize: The view from Pulltrouser Swamp. In McAnany, P. A., and Isaac, B. L. (eds.), Research in Economic Anthropology, Supplement 4, Prehistoric Maya Economies of Belize, JAI Press, Greenwich, pp. 91-111.

Garber, J. F. (1983). Patterns of jade consumption and disposal at Cerros, northern Belize. American Antiquity 48: 800-807.

Gibson, E. (1986). Diachronic Patterns of Lithic Production, Use and Exchange in the Southern Maya Lowlands, Ph.D. dissertation, Harvard University, Cambridge, MA.

Gill, R. (1990). The Classic Maya Collapse and Climatic Change, Master's thesis, Department of Anthropology, University of Texas, San Antonio.

Gómez Pompa, A., Salvador Flores, J., and Sosa, V. (1987). The "pet kot": A man-made tropical forest of the Maya. Interciencia 12: 10-15.

Graham, E. (1987). Resource diversity in Belize and its implications for models of exchange. American Antiquity 48: 800-807.

Grube, N. (1986). Die Hieroglyphenplattform von Kabah, Yucatan, Mexico. Mexicon 8: 13-17.

Grube, N. (1986). Untersuchungen zur dynastischen Geschichte von Naranjo, El Petén, Guatemala. Zeitschrift fur Ethnologie 111: 47-118.

Grube, N. (1990). A reference to Water Lily on Caracol Stela 16. Copan Note 68, IHAH, Tegucigalpa, Honduras.

Guderjan, T. H. (ed.) (1991). Maya Settlement in Northwestern Belize: The 1988 and 1990 Seasons of the Rio Bravo Archaeological Project, Labyrinthos, Culver City, CA.

Guderian, T. H., Garber, J. F, Smith, H. A., Stross, F., Michel, H. V., and Asaro, F. (1989). Maya maritime trade and sources of obsidian at San Juan, Ambergris Cay, Belize. Joumal of Field Archaeology 16: 363-369.

Hall, G. D. (1989). Realm of Death: Royal Mortuary Customs and Polity Interaction in the Classic Maya Lowlands, Ph.D. dissertation, Harvard University, Cambridge.

Hall, G. D., Tarka, S. M., Hurst, J., Stuart, D., and Adams, R. E. W. (1990). Cacao residues in ancient Maya vessels from Río Azul, Guatemala. American Antiquity 55: 138-143.

Hamblin, N. L. (1984). Animal Use by the Cozumel Maya, University of Arizona Press, Tucson.

Hamblin, R. L., and Pitcher, B. L. (1980). The Classic Maya collapse: Testing class conflict hypotheses. American Antiquity 45: 246-267.

Hammond, N. (1975). Maya settlement hierarchy in northern Belize. Contributions of the University of Califomia Archaeological Research Facility 27: 40-55 (Berkeley).

Hammond, N. (1991). The discovery of La Milpa. Mexicon 13: 46-50.

Hammond, N. (1991). Matrices and Maya archaeology. Joumal of Field Archaeology 18: 29-41.

Hammond, N. (1992). Preclassic Maya civilization. In Danien, E. C., and Sharer, R. J. (eds.) New Theories on the Ancient Maya, University Museum, University of Pennsylvania, Philadelphia, pp..137-144. 
Hammond, N., Aspinall, A., Feather, S., Hazelden, J., Gazard, T., and Agrell, S. (1977). Maya jade: Source location and analysis. In Earle, T., and Ericson, J. (eds.), Exchange Systems in Prehistory, Academic Press, New York, pp. 36-67.

Hammond, N., Kosakowsky, L. J., Pyburn, K. A., Rose, J. R., Staneko, J. C., Donaghey, S., Clark, C. M., Horton, M., Gleason, C., Muyskens, D., and Addyman, T. (1988). The evolution of an ancient Maya city: Nohmul. National Geographic Research 4: 474-495.

Hammond, N., Clarke, A., and Robin, C. (1991). Middle Preclassic buildings and burials at Cuello, Belize: 1990 investigations. Latin American Antiquity 2: 353-363.

Hammond, N., Clarke, A, and Estrada Belli, F. (1992). Middle Preclassic Maya buildings and burials at Cuello, Belize. Antiquity 66: 955-964.

Harrison, P. (1990). The revolution in ancient Maya subsistence. In Clancy, F. S., and Harrison, P. D. (eds.), Vision and Revision in Maya Studies, University of New Mexico Press, Albuquerque, pp. 99-113.

Harrison, P. (1993). Aspects of water management in the southern Maya lowlands. In Scarborough, V. L., and Isaac, B. L. (eds.), Research in Economic Anthropology, Supplement 7, JAI Press, Greenwich, CT, pp. 71-119.

Haviland, W. A. (1977). Dynastic genealogies from Tikal, Guatemala: Implications for descent and political organization. American Antiquity 42: 61-67.

Haviland, W. A. (1981). Dower houses and minor centers at Tikal, Guatemala: An investigation into the identification of valid units of settlement hierarchies. In Ashmore, W. (ed.), Lowland Maya Settlement Patterns, University of New Mexico Press, Albuquerque, pp. 335-349.

Haviland, W. A. (1985). Excavations in Small Residential Groups of Tikal: Groups $4 F-1$ and $4 F-2$, Tikal Report 19, University Museum, University of Pennsylvania, Philadelphia.

Haviland, W. A. (1988). Musical hammocks at Tikal: Problems with reconstructing household composition. In Wilk, R. R., and Ashmore, W. (eds.), Household and Community in the Mesoamerican Past, University of New Mexico Press, Albuquerque, pp. 121-134.

Healy, P. F. (1990). Excavations at Pacbitun, Belize: Preliminary report on the 1986 and 1987 investigations. Joumal of Field Archaeology 17: 247-262.

Healy, P. F., Lambert, J., Arnason, J., and Hebda, R. (1983). Caracol, Belize: Evidence of ancient Maya agricultural terraces. Joumal of Field Archaeology 10: 397-410.

Henderson, J. S. (1981). The World of the Ancient Maya, Cornell University Press, Ithaca.

Henderson, J. S., and Beaudry-Corbett, M. (eds.) (1994). Pottery of Prehistoric Honduras: Regional Classification and Analysis, Institute of Archaeology Monograph 35, UCLA, Los Angeles.

Hendon, J. A. (1991). Status and power in Classic Maya society: An archaeological study. American Anthropologist 93: 894-918.

Hester, T. R., and Shafer, H. J. (1992). Lithic workshops revisited: Comments on Moholy-Nagy. Latin American Antiquity 3: 243-248.

Hester, T. R., and Shafer, H. J. (eds.) (1991). Maya Stone Tools: Selected Papers from the Second Maya Lithic Conference, Prehistory Press, Madison, WI.

Hopkins, N. (1988). Classic Mayan kinship systems: Epigraphic and ethnographic evidence for patrilineality. Estudios de Cultura Maya 17: 87-121.

Jackson, L., and McKillop, H. (1987). Maya trade at Wild Cane Cay, Belize. Archaeology 40: 62-63.

Johnson, J. K. (1985). Postclassic Maya site structure at Topoxte, El Peten, Guatemala. In Chase, A. F., and Rice, P. M. (eds.), The Lowland Maya Postclassic, University of Texas Press, Austin, pp. 151-165.

Jones, G. D. (1989). Maya Resistance to Spanish Rule, University of New Mexico Press, Albuquerque.

Jones, G. D., Kautz, R. R., and Graham, E. (1986). Tipu: A Maya town on the Spanish Colonial frontier. Archaeology 39: 40-47.

Iceland, H. (1993). Analysis of an obsidian collection from Pulltrouser Swamp, Belize. In The Newsletter of the Friends of the Texas Archeological Research Laboratory, University of Texas, Austin, 1(2): 25-26. 
Kennedy, N. (1986), The periphery problem and Playa de los Muertos: A test case. In Urban, P., and Schortman, E. (eds.), The Southeast Maya Periphery, University of Texas Press, Austin, pp. 179-193.

Killion, T. (ed.) (1992). Gardens of Prehistory, University of Alabama Press, Tuscaloosa.

Kosakowsky, L. J. (1987). Preclassic Maya Pottery at Cuello, Belize, Anthropological Paper 47, University of Arizona, Tucson.

Kowalski, J. K. (1987). The House of the Govemor: A Maya Palace at Uxmal, Yucatan, Mexico, University of Oklahoma Press, Norman.

Kowalski, J. K (1989). "Who am I among the Itza?": Links between northern Yucatan and the western Maya lowlands and highlands. In Diehl, R. A., and Berlo, J. C. (eds.), Mesoamerica after the Decline of Teotihuacan, A. D. 700-900, Dumbarton Oaks, Washington, D. C., pp. 173-185.

Kowalski, J. K. (1990). A preliminary report on the 1988 field season at the Nunnery Quadrangle, Uxmal, Yucatan, Mexico. Mexicon 12: 27-33.

Kurjack, E. B., and Andrews, E. W., V (1976). Early boundary maintenance in northwest Yucatan, Mexico. American Antiquity 41: 318-325.

Lambert, J. D. H., and Arnason, J. T. (1982). Ramón and Maya ruins: An ecological, not an economic, relation. Science 216: 298-299.

Lange, F. W. (ed.) (1992). Wealth and Hierarchy in the Intermediate Area, Dumbarton Oaks, Washington, D. C.

Lange, F. W. (ed.) (1993). Precolumbian Jade: New Geological and Cultural Interpretations, University of Utah Press, Salt Lake City.

Lange, F. W., and Stone, D. (eds.) (1984). The Archaeology of Lower Central America, University of New Mexico Press, Albuquerque.

Laporte, J. P. (1987). El Grupo 6C-XVI, Tikal, Petén: Un centro habitacional del clásico temprano. Memorias del Primer Coloquio Internacional de Mayistas, UNAM, Mexico, pp. 221-243.

Laporte M., J. P. (1993). Architecture and social change in Late Classic Maya society: The evidence from Mundo Perdido, Tikal. In Sabloff, J. A., and Henderson, J. S. (eds.), Lowland Maya Civilization in the Eighth Century A. D., Dumbarton Oaks, Washington, D. C., pp. $299-320$.

Lentz, D. L. (1990). Acrocomia mexicana: Palm of the ancient Mesoamericans. Joumal of Ethnobiology 10: 183-194.

Lentz, D. L. (1991). Maya diets of the rich and poor: Paleobotanical evidence from Copan. Latin American Antiquity 2: 269-287.

Leventhal, R. M. (1981). Settlement patterns in the southeast Maya area. In Ashmore, W. (ed.), Lowland Maya Settlement Patterns, University of New Mexico Press, Albuquerque, pp. $187-210$.

Leventhal, R. M. (1983). Household groups and Classic Maya religion. In Vogt, E. Z., and Leventhal, R. M. (eds.), Prehistoric Settlement Pattems: Essays in Honor of Gordon R. Willey, University of New Mexico Press, Albuquerque, pp. 55-76.

Leventhal, R. M. (1990). The power of writing and the writing of power, paper presented at the annual meeting of the AAA, New Orleans.

Lewenstein, S. M. (1987). Stone Tool Use at Cerros: The Ethnoarchaeological and Use-Wear Evidence, University of Texas Press, Austin.

Lewenstein, S. M. (1991). Woodworking tools at Cerros. In Hester, T. R., and Shafer, H. J. (eds.), Maya Stone Tools: Selected Papers from the Second Maya Lithic Conference, Prehistory Press, Madison, WI, pp. 239-250.

Lopez V., S. L. (1989). Análisis y Clasificación de la Cerámica de un Sitio Maya del Clásico: Yaxchilán, México, British Archaeological Reports International Series 535, Oxford, England.

Love, M. W. (1991). Style and social complexity in Formative Mesoamerica. In Fowler, W. R. (ed.), The Formation of Complex Society in Southeastern Mesoamerica, CRC Press, Boca Raton, FL, pp. 47-76.

Lowe, J. W. G. (1985). The Dynamics of Apocalypse: A Systems Simulation of the Classic Maya Collapse, University of New Mexico Press, Albuquerque. 
MacKinnon, J. J., and Kepecs, S. M. (1991). Prehistoric saltmaking in Belize: A reply to Valdez and Mock and to Marcus. American Antiquity 56: 528-530.

Mallory, J. D. (1986). "Workshops" and "specialized production" in the production of Maya chert tools: A response to Shafer and Hester. American Antiquity 51: 152-158.

Manzanilla, L. (ed.) (1986). Unidades Habitacionales Mesoamericanas y Sus Areas de Actividad, UNAM, Mexico.

Manzanilla, L. (ed.) (1987). Cobá, Quintana Roo: Análisis de Dos Unidades Habitacionales Mayas del Horizonte Clásico, UNAM, Mexico.

Marcus, J. (1974). The iconography of power among the Classic Maya. World Archaeology 6: 83-94.

Marcus, J. (1978). Archaeology and religion: A comparison of the Zapotec and Maya. World Archaeology 10: 172-191.

Marcus, J. (1982). Review of Ashmore, W., Lowland Maya Settlement Patterns. American Antiquity 47: 899-902.

Marcus, J. (1983). On the nature of the Mesoamerican city. In Vogt, E. Z., and Leventhal, R. M. (eds.), Prehistoric Settlement Patterns: Essays in Honor of Gordon R. Willey, University of New Mexico Press, Albuquerque, pp. 195-242.

Marcus, J. (1984). Mesoamerican territorial boundaries: Reconstructions from archaeology and hieroglyphic writing. Archaeological Review from Cambridge 3: 48-62.

Marcus, J. (1989). From centralized systems to city states: Possible models for the Epiclassic. In Diehl, R. A., and Berlo, J. C. (eds.), Mesoamerica After the Decline of Teotihuacan: A. D. 700-900, Dumbarton Oaks, Washington, D. C., pp. 201-208.

Marcus, J. (1992). Royal families, royal texts: Examples from the Zapotec and Maya. In Chase, D. Z., and Chase, A. F. (eds.), Mesoamerican Elites, University of Oklahoma Press, Norman, pp. 221-241.

Massey, V. (1989). The Human Skeletal Remains from a Terminal Classic Skull Pit at Colha, Belize, Papers of the Colha Project, Vol. 3, Department of Anthropology, Texas A\&M, College Station.

McAnany, P. A. (1988). The effect of lithic procurement strategies on tool curation and recycling. Lithic Technology 17: 3-11.

McKillop, H. (1985). Prehistoric exploitation of the manatee in the Maya and Circum-Caribbean areas. World Archaeology 16: 337-353.

McKillop, H. (1989). Coastal Maya trade: Obsidian densities at Wild Cane Cay. In McAnany, P. A., and Isaac, B. L. (eds.), Research in Economic Anthropology Supplement 4, Prehistoric Maya Economies of Belize, JAI Press, Greenwich, pp. 17-56.

McKillop, H. (1994). Ancient Maya tree-cropping: A viable subsistence adaptation for the island Maya. Ancient Mesoamerica 5: 129-140.

McKillop, H., and Healy, P. F. (eds.) (1989). Coastal Maya Trade, Occasional Papers in Anthropology, Trent University, No. 8, Peterborough, Ontario, Canada.

Miller, M. E. (1986). The Murals of Bonampak, Princteon University Press, Princeton.

Millet, L., Ojeda, H., and Suárez, V. (1993). Tecoh, Izamal: nobleza indigena y conquista española. Latin American Antiquity 4: 48-58.

Mock, S. (1993). The Northern River Lagoon site (NRL): Settlement, saltmaking, and survival on the coast of Belize, Central America. The Newsletter of the Friends of Texas Archeological Research Laboratory, University of Texas, Austin, 1(2): 24.

Moholy-Nagy, H. (1990). The misidentification of Mesoamerican lithic workshops. Latin American Antiquity 1: 268-279.

Moholy-Nagy, H. (1991). The flaked chert industry of Tikal, Guatemala. In Hester, T. R., and Shafer, H. J. (eds.), Maya Stone Tools: Selected Papers from the Second Maya Lithic Conference, Prehistory Press, Madison, WI, pp. 189-202.

Moholy-Nagy, H. (1992). Lithic deposits as waste management: Reply to Healan and to Hester and Shafer. Latin American Antiquity 3: 249-251.

Moholy-Nagy, H., and Nelson, F. W. (1990). New data on sources of obsidian artifacts from Tikal, Guatemala. Ancient Mesoamerica 1: 71-80.

Morley, S. G., and Brainerd, G. W. (1956). The Ancient Maya, 3rd ed., Stanford University Press, Stanford, CA 
Netting, R., Wilk, R. R., and Arnould, E. J. (eds.) (1984). Households: Comparative and Historical Studies of the Domestic Group, University of California, Los Angeles.

Pendergast, D. M. (1979). Excavations at Altun Ha, Belize, 1964-1970, Vol. 1, Royal Ontario Museum, Toronto.

Pendergast, D. M. (1990). Up from the dust: The central lowlands Postclassic as seen from Lamanai and Marco Gonzales. In Clancy, F. S., and Harrison, P. D. (eds.), Vision and Revision in Maya Studies, University of New Mexico Press, Albuquerque, pp. 169-177.

Pendergast, D. M., Jones, G., and Graham, E. (1993). Locating Maya lowland Spanish Colonial towns: A case study from Belize. Latin American Antiquity 4: 59-73.

Pohl, M. (ed.) (1985). Prehistoric Lowland Maya Environment and Subsistence Economy, Papers of the Peabody Museum, Vol. 77, Harvard University, Cambridge.

Pohl, M. (1990). The ethnozoology of the Maya: Faunal remains from five sites in Peten, Guatemala. In Willey, G. (ed.), Excavations at Seibal, Guatemala, Memoirs of the Peabody Museum, Harvard University 17, No. 3, Cambridge, pp. 142-174.

Pohl, M. (ed.) (1990). Ancient Maya Wetland Agriculture: Excavations on Albion Island, Northern Belize, Westview Press, Boulder, CO.

Pohl, M., and Bloom, P. (1994). Prehistoric farming in the wetlands of northern Belize: Albion Island and beyond. In Fedick, S., and Aliphat F., M. (eds.), Ancient Maya Agriculture and Biological Resource Management, Mexico (in press).

Pohl, M., and Pohl, J. (1994). Cycles of conflict: Political factionalism in the Maya lowlands. In Brumfiel, E. M., and Fox, J. W. (eds.), Factional Competition and Political Development in the New World, Cambridge University Press, Cambridge, pp. 138-157.

Pope, K. O., and Dahlin, B. H. (1989). Ancient Maya wetland agriculture: New insights from ecological and remote sensing research. Joumal of Field Archaeology 16: 87-106.

Puleston, D. E. (1974). Intersite areas in the vicinity of Tikal and Uaxactun. In Hammond, N. (ed.), Mesoamerican Archaeology: New Approaches, Duckworth, London, pp. 303-311.

Puleston, D. E., and Callender, D. W. (1967). Defensive earthworks at Tikal. Expedition 9: $40-48$.

Pyburn, K. A. (1989). Maya cuisine: Hearths and the lowland Maya economy. In McAnany, P. A, and Isaac, B. L. (eds.), Research in Economic Anthropology Supplement 4, Prehistoric Maya Economies of Belize, JAI Press, Greenwich, CT, pp. 325-344.

Rands, R. L. (1967). Ceramic technology and trade in the Palenque Region, Mexico. In Riley, C. L., and Taylor, W. W. (eds.), American Historical Anthropology, Southern Illinois University, Carbondale, pp. 137-151.

Rands, R. L., and Bishop, R. L. (1980). Resource procurement zones and patterns of ceramic exchange in the Palenque region, Mexico. In Fry, R. E. (ed.), Models and Methods in Regional Exchange, Society for American Archaeology Papers, No. 1, Washington, DC, pp. $19-46$.

Reina, R. E., and Hill, R. M. (1986). Lowland Maya subsistence: Notes from ethnohistory and ethnography. American Antiquity 45: 74-79.

Rice, D. S. (1988). Classic to Postclassic Maya household transitions in the central Peten, Guatemala. In Wilk, R. R., and Ashmore, W. (eds.), Household and Community in the Mesoamerican Past, University of New Mexico Press, Albuquerque, pp. 227-247.

Rice, D. S. (1991). Roots: Resourceful Maya farmers enabled a mounting population to survive in a fragile tropical forest habitat. Natural History 2: 10-14.

Rice, D. S., and Rice, P. M. (1984a). Lessons from the Maya. Latin American Research Review 19: 7-34.

Rice, D. S., and Rice, P. M. (1984b). Collapse to contact: Postclassic archaeology of the Peten Maya. Archaeology 37: 46-51.

Rice, D. S., Rice, P. M., and Deevey, E. S. (1985). Paradise lost: Classic Maya impact on a lacustrine environment. In Pohl, M. (ed.), Prehistoric Lowland Maya Environment and Subsistence Economy, Papers of the Peabody Museum, Vol. 77, Harvard University, Cambridge, MA, pp. 91-105.

Rice, P. M. (1987). Economic change in the lowland Maya Late Classic period. In Brumfiel, E. M., and Earle, T. K. (eds.), Specialization, Exchange, and Complex Societies, Cambridge University Press, Cambridge, pp. 75-85. 
Riese, B. (1986). Late Classic relationship between Copan and Quirigua: Some epigraphic evidence. In Urban, P. A., and Schortman, E. M. (eds.), The Southeast Maya Periphery, University of Texas Press, Austin, pp. 94-101.

Riese, B. (1988). Epigraphy in the southeast zone in relation to other parts of Mesoamerica In Boone, E. H., and Willey, G. R. (eds.), The Southeast Classic Maya Zone, Dumbarton Oaks, Washington, D. C., pp. 67-94.

Ringle, W. (1985a). The Settlement Patterns of Komchen, Yucatan, Mexico, Ph.D. dissertation, Tulane University, New Orleans.

Ringle, W. (1985b). Notes on two tablets of unknown provenance. In Robertson, M. G., and Fields, V. M. (eds.), Fifth Palenque Round Table, 1983, Vol. VII, Pre-Columbian Art Research Institute, San Francisco, pp. 151-158.

Ringle, W. (1990). Who was who in ninth-century Chichen Itza. Ancient Mesoamerica 1: 233-243.

Ringle, W., Bey, G., and Peraza L., C. (1991). Preliminary Report of the Proyecto Ek Balam, manuscript submitted to National Geographic Society.

Robinson, E. (ed.) (1987). Interaction on the Southeast Mesoamerican Frontier, BAR International Series 327, Oxford, England.

Rue, D. (1987). Early agriculture and Early Postclassic Maya occupation in western Honduras. Nature 326: 285-286.

Sabloff, J. A. (1986). Interaction among Classic Maya polities: A preliminary examination. In Renfrew, C., and Cherry, J. F. (eds.), Peer Polity Interaction and Socio-Political Change, Cambridge University Press, Cambridge, pp. 109-116.

Santley, R. S., and Hirth, K. G. (eds.) (1993). Prehispanic Domestic Units in Westem Mesoamerica: Studies of the Household, Compound, and Residence, CRC Press, Boca Raton, FL.

Scarborough, V. L. (1991). Archaeology at Cerros, Belize, Central America, Vol. III: The Settlement System in a Late Preclassic Maya Community, Southern Methodist University, Dallas.

Scarborough, V. L., and Gallopin, G. G. (1991). A water storage adaptation in the Maya lowlands. Science 251: 658-662.

Scarborough, V. L., and Isaac, B. L. (eds.) (1993). Research in Economic Anthropology, Supplement 7: Economic Aspects of Water Management in the Prehispanic New World, JAI Press, Greenwich, CT.

Schele, L. (1992). The founders of lineages at Copan and other Maya sites. Ancient Mesoamerica 3: 135-144.

Schele, L., and Miller, J. (1983). The mirror, the rabbit, and the bundle: "Accession" expressions from the Classic Maya inscriptions. In Studies in Pre-Columbian Art and Archaeology 25, Dumbarton Oaks, Washington, DC.

Schortman, E. M. (1993). Archaeological Investigations in the Lower Motagua Valley, Izabal, Guatemala. Quirigua Reports, No. 3, University Museum, University of Pennsylvania, Philadelphia.

Schortman, E. M., and Urban, P. A. (eds.) (1992). Resources, Power, and Interregional Interaction, Plenum Press, New York.

Schortman, E. M., and Urban, P. A. (eds.) (1994). Sociopolitical hierarchy and craft production: The economic bases of elite power in a southeast Mesoamerican polity, Part III-the 1992 season of the Naco Valley Archaeological Project (manuscript).

Shafer, H. J., and Hester, T. R. (1986). Maya stone tool craft specialization and production at Colha, Belize: Reply to Mallory. American Antiquity 51: 158-166.

Shafer, H. J., and Hester, T. R. (1991). Lithic craft specialization and product distribution at the Maya site of Colha, Belize. World Archaeology 23: 79-97.

Sharer, R. J. (1978). Archaeology and history at Quiriguá, Guatemala. Journal of Field Archaeology 5: 51-70.

Sharer, R. J. (1985). Terminal events in the southeastern lowlands: A view from Quirigua. In Chase, A. F., and Rice, P. M. (eds.), The Lowland Maya Postclassic, University of Texas Press, Austin, pp. 245-253. 
Sharer, R. J. (1990). Quirigua: A Classic Maya Center and its Sculpture, Carolina Academic Press, Durham, NC.

Sharer, R. J. (1994). The Ancient Maya, 5th ed., Stanford University Press, Stanford, CA.

Sharer, R. J. (ed.) (1978). The Prehistory of Chalchuapa, El Salvador, 3 vols., University of Pennsylvania, Philadelphia.

Sheehy, J. (1991). Structure and change in a Late Classic Maya domestic group at Copan, Honduras. Ancient Mesoamerica 2: 1-19.

Sheets, P. (ed.) (1983). Archaeology and Volcanism in Central America: The Zapotitan Valley of El Salvador, University of Texas, Austin.

Sheets, P. (1991). Flaked lithics from the Cenote of Sacrifice, Chichén Itzá, Yucatán. In Hester, T. R., and Shafer, H. J. (eds.), Maya Stone Tools: Selected Papers from the Second Maya Lithic Conference, Prehistory Press, Madison, WI, pp. 163-187.

Sheets, P., and Simmons, S. (eds.) (1993). Preliminary Report of the Cerén Research Project, 1993 Season, Dept. of Anthropology, University of Colorado, Boulder.

Sievert, A. K. (1992). Maya Ceremonial Specialization: Lithic Tools from the Sacred Cenote at Chichén Itzá, Yucatán, Monographs in World Archaeology, No. 12, Prehistory Press, Madison, WI.

Smyth, M. P. (1990). Maize storage among the Puuc Maya: The development of an archaeological method. Ancient Mesoamerica 1: 51-69.

Smyth, M. P., and Dore, C. (1992). Large site archaeological methods at Sayil, Yucatan Investigating community organization at a prehispanic Maya center. Latin American Antiquity 3: 3-21.

Smyth, M. P., and Dore, C. (1994). Maya urbanism at Sayil, Yucatan. National Geographic Research \& Exploration 10: 38-55.

Stein, B. (1977). The segmentary state in south Indian history. In Fox, R. G. (ed.), Realm and Region in Traditional India, Monograph 14, Duke University, Durham, pp. 3-51.

Storey, R. (1992). The children of Copan: Issues in paleopathology and paleodemography. Ancient Mesoamerica 3: 161-167.

Stuart, D, and Schele, L. (1986). Yax k'uk mo', the founder of the lineage of Copan. Copan Note 6, IHAH, Tegucigalpa, Honduras.

Tambiah, S. J. (1976). The galactic polity: The structure of traditional kingdoms in southeast Asia. Annals of the New York Academy of Sciences, Vol. 293, pp. 69-97.

Tate, C. E. (1992). Yaxchilán, University of Texas Press, Austin.

Tedlock, D. (1985). Popol Vuh, Simon and Schuster, New York.

Tobey, M. H. (1986). Trace Element Investigations of Maya Chert from Belize, Papers of the Colha Project, Vol. 1, Center for Archaeological Research, University of Texas at San Antonio.

Tourtellot, G., III (1988). Excavations at Seibal, Department of Peten, Guatemala: Peripheral Survey and Excavation, Settlement and Community Patterns, Memoirs of the Peabody Museum, 16, Harvard University, Cambridge.

Tozzer, A. M. (ed.) (1941). Landa's Relación de las Cosas de Yucatán, Papers of the Peabody Museum, Vol. 18, Harvard University, Cambridge.

Urban, P. A., and Schortman, E. M. (eds.) (1986). The Southeast Maya Periphery, University of Texas Press, Austin.

Valdés, J. A. (1986). Uaxactun: Recientes investigaciones. Mexicon 8: 125-128.

Valdez, F., and Mock, S. B. (1991). Additional considerations for prehispanic saltmaking in Belize. American Antiquity 56: 520-525.

Valdez, F., and Potter, D. R. (1991). Chert debitage from the Haryard Copán excavations: Descriptions and comments. In Hester, T. R., and Shafer, H. J. (eds.), Maya Stone Tools: Selected Papers from the Second Maya Lithic Conference, Prehistory Press, Madison, WI, pp. 203-206.

Voorhies, B. (ed.) (1989). Ancient Trade and Tribute: Economies of the Soconusco Region of Mesoamerica, University of Utah Press, Salt Lake City.

Webster, D. (1975). Warfare and the evolution of the state: A reconsideration. American Antiquity 40: 464-470. 
Webster, D. (1978). Three walled sites of the northern Maya lowlands. Journal of Field Archaeology 5: 375-390.

Webster, D. (1979). Cuca, Chaccob, Dzonot Aké: Three Walled Northern Maya Centers, Occasional Papers in Anthropology, No. 11, Department of Anthropology, Pennsylvania State University, University Park.

Webster, D. (1988). Copan as a Classic Maya center. In Boone, E. H., and Willey, G. R. (eds.), The Southeast Classic Maya Zone, Dumbarton Oaks, Washington, DC, pp. 5-30.

Webster, D. (ed.) (1989). The House of the Bacabs, Copan, Honduras, Studies in Pre-Columbian Art and Archaeology 29, Dumbarton Oaks, Washington, DC.

Webster, D., and Abrams, E. (1983). An elite compound at Copan, Honduras. Joumal of Field Archaeology 10: 285-296.

Weeks, J. M. (1983). Chisalin: A Late Postclossic Maya Settlement in Highland Guatemala, British Archaeological Reports International Series 169, Oxford, England.

Welsh, W. B. M. (1988). An Analysis of Classic Lowland Maya Burials, British Archaeological Reports International Series 409, Oxford, England

Wilk, R. R., and Rathje, W. L. (1982). Household archaeology. American Behavioral Scientist 25: 617-639.

Willey, G. R., and Mathews, P. (eds.) (1985). A Consideration of the Early Classic Period in the Maya Lowlands, Institute of Mesoamerican Studies, Publication No. 10, State University of New York, Albany.

Wonderley, A W. (1981), Late Postclassic Occupations at Naco, Honduras, Latin American Studies Program Dissertation Series, 86, Cornell University, Ithaca, NY.

Wonderley, A. W. (1985). The land of Ulua: Postclassic research in the Naco and Sula valleys, Honduras. In Chase, A. F., and Rice, P. M. (eds.), The Lowland Maya Postclassic, University of Texas Press, Austin, pp. 254-269.

Wonderley, A. W. (1986). Naco, Honduras: Some aspects of a late pre-columbian community on the eastern Maya frontier. In Urban, P. A., and Schortman, E. M. (eds.), The Southeast Maya Periphery, University of Texas Press, Austin, pp. 313-332. 